\title{
Remote Sensing for Irrigation of Horticultural Crops
}

\author{
Arturo Alvino * and Stefano Marino * \\ Department of Agricultural, Environmental and Food Sciences (DAEFS), University of Molise, Via De Sanctis, \\ 86100 Campobasso, Italy \\ * Correspondence: alvino@unimol.it (A.A.); stefanomarino@unimol.it (S.M.); Tel.: +39-0874-404676 \\ Academic Editor: Douglas D. Archbold \\ Received: 20 January 2017; Accepted: 31 May 2017; Published: 16 June 2017
}

\begin{abstract}
This paper reviews the literature on applications of remote sensing for monitoring soil- and crop- water status for irrigation purposes. The review is organized into two main sections: (1) sensors and platforms applied to irrigation studies and (2) remote sensing approaches for precision irrigation to estimate crop water status, evapotranspiration, infrared thermography, soil and crop characteristics methods. Recent literature reports several remote sensing (RS) approaches to monitor crop water status in the cultivated environment. Establishing the right amount of water to supply for different irrigation strategies (maximization of yield or water use efficiency (WUE)) for a large number of crops is a problem that remains unresolved. For each crop, it will be necessary to create a stronger connection between crop-water status and crop yield.
\end{abstract}

Keywords: crop water status; water use efficiency (WUE); platforms; sensors; evapotranspiration (ET); Crop water stress index (CWSI); time-temperature threshold (TTT); vegetation indices (VIs)

\section{Introduction}

Food is the basic and compulsory human requirement. It is expected that limited land and inadequate water resources will negatively impact the expected increase in demand for food crops during the next fifty years [1-3]. Subject to scenarios used, and assumptions and models employed, different forecasts have been made for food and agricultural production and related irrigation water needs. Food and Agriculture Organization (FAO) projections indicated a growth rate of world consumption of agricultural products of $1.1 \%$ per year for the period from 2005 to 2050. In order to meet this projected global demand, agricultural production would have to increase by $60 \%$ from 2005 to $2050[4,5]$.

Production of food requires water. Since water resources are a limiting factor for human actions, Water Use Efficiency (WUE) will be a crucial factor [6]. For these reasons, the European Parliament, in agreement with the Horizon 2020 program, has coined the phrase "produce more with less" [7]. Agriculture is the main user of water worldwide, accounting for about $70 \%$ of total water withdrawals, including the water used in livestock and aquaculture production [8]. Furthermore, it is expected that this sector will witness increased water consumption of about $20 \%$ by the year 2025 [9]. Thus, it is widely expected that the competition for water resources in many regions will increase. To meet the increasing population's demands for food and for water, it is critical to improve agricultural water productivity, or economic yield per volume of water used [1,10].

Forty percent of total agricultural production comes from the $20 \%$ of the land that is irrigated [11]. Farmers in developing countries have to improve agronomic and water management practices in order to increase WUE in all agroecosystems (from fully-rainfed to fully-irrigated farming systems). Pereira et al., [12] reported that the above goal is chiefly important where water is a scarce commodity (arid and semiarid regions). In these regions, it will be crucial to increase water productivity rather than maximizing crop yield. Molden et al. [13] suggested, "The adoptions of techniques to improve water 
productivity will require an enabling policy and an institutional environment that aligns the incentives of producers, resource managers and society, and provides a mechanism for dealing with trade-offs". Irrigation water management is sustainable if it realizes the objectives of preserving the natural environment and sustaining irrigated agriculture for food security. Appropriate irrigation practices are aimed at improving WUE in order to save water and maintain satisfactory yields [14].

Painter and Carren [15] emphasized the importance of reducing water losses below the root zone, improving yield and crop quality, conserving the resource base, and lowering the risk of salinization of groundwater to enhance sustainability. The authors also pointed out that "these gains can only be achieved when all elements of precision operate synergistically within a given environment".

For improving WUE at the regional level, Batchelor [16] suggested four methods of agronomic improvements: (1) rely on improved crop husbandry; (2) introduce varieties with higher productivity; (3) maximize cropped area during periods of low potential evapotranspiration and (4) when rainfall is highest, promote water recycling.

Wallace and Batchelor [17] reported four categories (agronomic, technical, managerial, and institutional) for improving the efficiency of irrigation. Technical solutions may improve irrigation uniformity, reduce leaching, and lead to adoption of irrigation practices that increase rainfall effectiveness. Among managerial improvements, the authors highlighted the implementation of irrigation scheduling systems based on crop demand. The institutional improvements "rely on the user involvement in scheme operation and maintenance; introduction of water pricing and legal frameworks to provide incentives for efficient water use and disincentives for inefficient use; introduction of integrated catchment management; improved training and extension". In 2005, Johansson [6] emphasized the importance at the farm level of the extension services for improving information or of cheap credit for adjusting to the changing environments associated with water policy reforms (water-pricing reforms, particularly).

Because more efficient irrigation practices can optimize WUE [18], and drip irrigation reduced crop evapotranspiration losses and runoff [19-21], the technology was appropriate for applying water to orchards and vegetables [22]. Proper irrigation (timing and amount) increased the crop WUE and crop yield [23]. In contrast, improper irrigation can lead to the onset of crop water deficits causing water and nutrient deficiencies that reduce yield [23,24]. Nevertheless, regardless of the strategy engaged, the benefits of irrigation scheduling can be reached only by applying the exact amount of water required [25]. Raine et al. [26] define precision irrigation as "the accurate and precise application of water to meet the specific requirements of individual plants or management units and minimize adverse environmental impact". Monitoring water use and crop water status in the field is important for developing effective precautions, and for this purpose, some indicators are required [27]. A very large body of research, spanning almost four decades, has demonstrated that much of the required agricultural information can be derived from remotely sensed data [28] starting from crop water status detection. IN order to develop effective irrigation strategies, it is necessary to identify the appropriate indicators for monitoring crop water status at the farm level [27]. For these purposes, the required agricultural information may be derived from remotely sensed data [28].

\section{Scope of the Review}

The applications of remote sensing to irrigation monitoring and management are reviewed herein. The assessment of the ideal crop water requirement is indispensable for several objectives linked to agronomic, economic, and environmental issues: (i) maximize crop yield (the 'yield gap'); (ii) stabilize production by adopting a safeguard against the vagaries of weather; (iii) ameliorate crop quality; (iv) save water; (v) limit onset of diseases; and (vi) limit groundwater pollution caused by $\mathrm{N}$ leaching losses. A seventh (vii) crucial point is the 'yield gap' of the environment under study. This means defining the potential and constraints of the field environment (sub optimal management, inappropriate technology, and/or lack of training of farmers). This is possible when water constraints on crop production are removed by using appropriate irrigation scheduling for getting more crop yield per drop of water $[9,29]$, contributing to social growth of the irrigated area. 
In 2008, Fereres [8] called for a more efficient and sustainable irrigation than in the past, at a time when the rate of irrigation was expected to slow down, and when the investments in irrigation and drainage were on the decline. Fereres also emphasized challenges in irrigated agriculture due to modernization of irrigation networks and management, the improvement of water institutions, and the responses to periodic droughts. The last point has imposed the introduction of new water saving technologies in horticulture.

A holistic approach is necessary for moving from a traditional approach to precision irrigation, defined as site-specific irrigation management that relies on the variable application of water according to soil and crop variability. It is a potential solution for increasing productivity and reducing the environmental impact of irrigated agriculture. A holist approach needs a deep and precise knowledge of the crop water requirements and the cultivated environment. The innovative deficit irrigation and partial root drying management strategies [29] have encouraged the development of new methods for monitoring water stress (abiotic). Fernández [30] focused on plant-based methods that integrate the soil and atmospheric water status and the plant response to the surrounding conditions.

The present review describes the role of remote sensing with respect to crop water status, its surface energy balance, the relationship between surface temperature and remotely sensed vegetation indices, and WUE and evapotranspiration. This review is limited to field-key studies, and presents applications of remote sensing for managing irrigation and water resources for meeting the current and future challenges of agricultural water resources management. A list of references is presented as a good resource for any who are interested in remote sensing applied to irrigation studies. The review is organized into the following main sections: (1) Sensors and platforms applied to irrigation studies; (2) Remote sensing approaches for precision irrigation for estimating crop water status, evapotranspiration, infrared thermography, and soil and crop characteristics.

\section{Sensors and Platforms}

Jensen et al. [31] reported that the first aerial images were taken by a camera mounted on a balloon around 1859. From the very beginning of satellite-based remote sensing in the 1970s, the use of remote sensing for terrestrial applications has increased tremendously [32]. Remote sensing is the acquisition of information about an object, or event through the analysis of data acquired obtained by a device without contact with the target under investigation [33]. The term remote sensing includes all the traditional primary mapping data acquisition technologies [34].

Remote-sensing instruments are designed to identify various wavelengths of the electromagnetic spectrum referred to as a "band" or "channel". Each instrument is characterized by a specific number and widths of wavelengths detected; some instruments detect discrete bands, while others detect fairly narrow wavelengths or broader bands (multispectral, visible and near-infrared wavelengths, microwave, thermal sensing systems) [35-37].

Remote sensing is able to identify spectral signatures of all surfaces and objects. Sensors can sense targets with a specific spatial resolution of image data defined by the smallest spatial area sampled or viewed. Digital images are made up of pixels, each pixel characterized by specific spectral and spatial attributes [38], as the intensity of reflectance or emittance measured by a sensor [39]. Spatial resolution corresponds to the spatial area each displayed or printed pixel represents.

When the time image was shot (day or year) is a crucial point in interpreting remotely sensed data analysis [40]. If the same area is imaged in the morning and late afternoon, a greater number of features with different orientations may be discerned than if the area is only imaged in the morning [41]; this is especially true when interpreting vegetation classes. Multi-temporal images are taken at different times to monitor changes in the environment and to analyze numerous processes [42,43]. The temporal dynamics may range from hours to a number of years. Sexton et al. [44] and Guerschman et al. [45] reported that "to assess changes over a time sequence accurately, effects in the data not caused by true environmental changes (such as differing atmospheric conditions and sun or view angle positions) must first be accounted for". 
Other sensors are defined as bidirectional, due to the illumination angle at which the energy source strikes the target, and the position (angle) at which the instrument receives the emitted or the reflected energy (called the view angle) as described by Schowengerdt [46] and Campbell and Wynn [47].

\subsection{Remote Sensing Sensors}

Different remote sensing sensors have been developed for monitoring crop growth and yield, as well as the spatial variability within fields. Many factors may affect crop growth and yield variability, such as soil characteristics, soil fertility, soil moisture, canopy volume, biomass and architecture, water content, and biotic and abiotic stress. Different types of sensors can monitor and measure these factors; Lee et al. [48] discussed electronic sensors, spectroradiometers, machine vision, multispectral and hyperspectral sensors, thermal sensors, and machine olfaction systems. A detailed review on sensors related to agricultural crop was reported by Ruiz-Altisent et al. [49]. The authors provided an overview of sensing technologies and application as: (i) electromagnetic sensors, spectroscopic sensors, and computer vision; (ii) mechanical contact and acoustic sensors; (iii) biosensors; and (iv) wireless-sensor networks. Wang et al. [50] studied recent development and future perspective of wireless sensors in agriculture and the food industry.

Sensors can be divided into several broad categories of basic sensor system types such as active and passive. Passive sensors (photographic, electro-optic radiometers, passive microwave systems visible, infrared, and thermal imaging systems, etc.) are the most common for vegetation correlated remote sensing. These sensors provide helpful information for crop monitoring, but their major limitation is the strong relationship among data acquisition and lighting (time of day and year; latitude) and weather conditions (cloud cover). Data from passive sensors requires accurate measurements of solar radiation and correction for "atmospheric effects" [34,40].

Active sensors use an artificial source of energy; in active remote sensing, humans can control the nature (wavelength, power, duration) of the source energy. Active sensors (Radar systems, LiDAR) do not need sun light and perfect weather conditions (less dependence on environmental factors); therefore, they can be more dedicated and targeted toward the remote sensing objectives even at night or under adverse conditions (haze, clouds, rain, etc.) [34,40].

\subsection{Remote Sensing Platforms}

The platform on which a particular sensor is lodged states the distance of the sensor from the target, timing, periodicity, location, and extent of coverage of the acquired image. The detailed information obtained is strictly related to the distance between the object of interest and the type of platform. Remote sensing platforms can be divided into three groups: satellite, airborne and Unmanned Aerial Vehicles (UAVs), and ground based solutions. According to Matese et al. [51], each of these platforms and sensors shows strengths and weaknesses related to technological, operational and economic factors.

\subsubsection{Satellite}

Satellites can be classified by (i) altitude; (ii) orbital geometry (geostationary, equatorial and sun synchronous) and (iii) timing. Regarding the first point, there are space shuttles orbiting around 250-300 km above the earth; space stations orbiting from 300 to $400 \mathrm{~km}$ above; low level satellites from 700 to $1500 \mathrm{~km}$ above, and high-level satellites, about $36000 \mathrm{~km}$ above the earth's surface. The first remote sensing satellite appeared in 1960 for meteorological purposes. Geostationary satellites have a $24 \mathrm{~h}$-period of rotation, so they always stay over the same earth location. Usually, communications and weather satellites have often-geostationary orbits, generally located over the equator. To ensure repeatable sun illumination conditions during specific seasons, sun synchronous satellites have orbits nearly passing over the poles. Sensor and orbital characteristics determine the frequency of data acquisition (Table 1). The satellite frequency ranges from twice a day to every 16 days. 
Table 1. Satellites for agricultural purposes.

\begin{tabular}{|c|c|c|c|c|}
\hline Satellite & Resolution & Revisit (Days) & Instruments & Field of Application \\
\hline Aqua & & & $\begin{array}{l}\text { Multichannel Microwave } \\
\text { Radiometer (Passive Sensor) }\end{array}$ & $\begin{array}{l}\text { Precipitation, oceanic water vapor, } \\
\text { cloud water, }\end{array}$ \\
\hline Cloudsat & $1.7 \mathrm{~km}$ & & radar (active sensor) & cloud liquid water and ice water contents \\
\hline Geoeye-1 & $\begin{array}{l}0.46 \mathrm{~m} \text { panchromatic } \\
(\mathrm{B} \& W) \text { and } 1.84 \mathrm{~m} \\
\text { multispectral resolution }\end{array}$ & from 2.1 to 8.3 & $\begin{array}{l}\text { Simultaneous panchromatic and } \\
\text { multispectral (pan-sharpened) } \\
\text { Panchromatic only; } \\
\text { Multispectral only }\end{array}$ & $\begin{array}{l}\text { It features the most sophisticated technology } \\
\text { ever used in a commercial remote } \\
\text { sensing system }\end{array}$ \\
\hline IKONOS & 0.82 & 3 & $\begin{array}{l}3.2 \mathrm{~m} \text { multispectral, Near-Infrared } \\
\text { (NIR) } 0.82 \mathrm{~m} \text { panchromatic } \\
\text { resolution at nadir. }\end{array}$ & $\begin{array}{l}\text { Rural mapping of natural resources and of } \\
\text { natural disasters, tax mapping, agriculture }\end{array}$ \\
\hline $\begin{array}{c}\text { Landsat } 7 \\
(\mathrm{ETM}+)\end{array}$ & $15-30 \mathrm{~m}$ & 16 & Radiometer (Passive Sensor) & $\begin{array}{l}\text { It detects spectrally-filtered radiation in } \\
\text { VNIR, SWIR, LWIR and panchromatic bands } \\
\text { from the sun-lit Earth in a } 183 \mathrm{~km} \text { wide } \\
\text { swath when orbiting at an altitude of } 705 \mathrm{~km} \text {. }\end{array}$ \\
\hline Landsat 8 & $15-100$ & 16 & $\begin{array}{l}\text { Two main sensors: the } \\
\text { Operational Land Imager (OLI) } \\
\text { and the Thermal Infrared Sensor } \\
\text { (TIRS) }\end{array}$ & $\begin{array}{l}\text { It collects images using nine spectral bands in } \\
\text { different wavelengths of visible, } \\
\text { near-infrared, and shortwave light to observe } \\
\text { a } 185 \mathrm{~km} \text { ( } 115 \text { mile) wide swath of the Earth } \\
\text { in } 15-30 \mathrm{~m} \text { resolution covering wide areas of } \\
\text { the Earth's landscape while providing } \\
\text { sufficient resolution to distinguish features } \\
\text { like urban centers, farms, forests and other } \\
\text { land uses. }\end{array}$ \\
\hline Pleiades-1A & $0.5 \mathrm{~m}$ & 1 & $\begin{array}{l}50 \mathrm{~cm} \text { B\&W; } 50 \mathrm{~cm} \text { color; } 2 \mathrm{~m} \\
\text { multispectral. Bundle: } 50-\mathrm{cm} \\
\text { B\&W and 2-m multispectral }\end{array}$ & $\begin{array}{l}\text { It provides color products at } 50 \mathrm{~cm} \text { that } \\
\text { deliver an extremely high level of detail. } \\
\text { High location accuracy and excellent image } \\
\text { quality for precision mapping. }\end{array}$ \\
\hline QuickBird & $\begin{array}{l}\text { Pan: } 65 \mathrm{~cm} \text { (nadir) to } \\
73 \mathrm{~cm}\left(20^{\circ} \text { off-nadir }\right) \\
\text { MS: } 2.62 \mathrm{~m} \text { (nadir) to } \\
2.90 \mathrm{~m}\left(20^{\circ} \text { off-nadir }\right)\end{array}$ & $\begin{array}{l}1-3-5 \text { (depending } \\
\text { on latitude) }\end{array}$ & Panchromatic and Multispectral & $\begin{array}{l}\text { Useful for analyses of changes in land usage, } \\
\text { agricultural and forest climates }\end{array}$ \\
\hline Rapideye & $5 \mathrm{~m}$ & $\begin{array}{l}1 \text { (off-nadir) } 5.5 \\
\text { days (at nadir) }\end{array}$ & Multispectral & $\begin{array}{l}\text { It includes the Red-Edge band, which is } \\
\text { sensitive to changes in chlorophyll content }\end{array}$ \\
\hline Sentinel-2 & 10 to $60 \mathrm{~m}$ & 5 & MSI (Multispectral Imager) & $\begin{array}{c}\text { Generic land cover, land use and } \\
\text { change detection maps } \\
\text { Maps of geophysical variables for leaf area } \\
\text { index, leaf chlorophyll content, } \\
\text { leaf water content }\end{array}$ \\
\hline SMAP & $35 \mathrm{~km}$ & 3 & radar (active sensor) & $\begin{array}{c}\text { It measures the amount of water in the top } \\
5 \mathrm{~cm} \text { ( } 2 \text { inches) of soil everywhere on Earth's } \\
\text { surface. Surface features are used to monitor } \\
\text { water and energy fluxes, and play a crucial } \\
\text { role in understanding changes in } \\
\text { water availability }\end{array}$ \\
\hline SMOS & $35 \mathrm{~km}$ & 3 & $\begin{array}{l}\text { microwaves radiation } \\
\quad(\mathrm{L}-\text { bad } 1.4 \mathrm{GHz})\end{array}$ & $\begin{array}{l}\text { Sea Surface Salinity over oceans and Soil } \\
\text { Moisture over land for climatologic, } \\
\text { meteorological, hydrologic, and } \\
\text { oceanographic applications. }\end{array}$ \\
\hline
\end{tabular}


Table 1. Cont.

\begin{tabular}{ccccc}
\hline Satellite & Resolution & Revisit (Days) & Instruments & Field of Application \\
\hline Worldwide-1 & $0.46 \mathrm{~m}$ & 1.7 & Panchromatic & $\begin{array}{c}\text { Provides highly detailed imagery for precise } \\
\text { map creation, change detection, and in-depth } \\
\text { image analysis }\end{array}$ \\
Worldwide-2 & $0.46 \mathrm{~m}$ & 1.1 & $\begin{array}{c}\text { High-resolution panchromatic } \\
\text { band and eight multispectral } \\
\text { bands; four standard colors (red, } \\
\text { green, blue, and near-infrared (1) } \\
\text { and four new bands (coastal, } \\
\text { yellow, red edge, and } \\
\text { near-infrared (2). }\end{array}$ & $\begin{array}{c}\text { It collects very large areas of multispectral } \\
\text { imagery ingle pass. It performs precise } \\
\text { change detection and mapping. }\end{array}$ \\
\hline
\end{tabular}

Source: Satellite Imaging Corporation (http://www.satimagingcorp.com/satellite-sensors/); Earth Data (NASA) https://earthdata.nasa.gov/user-resources/remote-sensors; EO-Sharing Earth Observation Resources https:// directory.eoportal.org/web/eoportal/satellite-missions/g.

Toth and Jóźków [34] reported on new satellite technologies related to microsatellites and nanosatellites, which increment the number of observations by sharing the same orbit. One of the first examples comes from Planet Labs, which launched four prototype satellites in order to test the performance of the system [34].

Satellite constellations (Landsat, SPOT, Global Navigation Satellite System and GeoEye/WorldView families; Rapid Eye) have identical satellites positioned on the same orbit to diminish the revisit time [52,53].

Satellites that operate in dual mode are defined as a constellation, such as GOCE and the dual GRACE satellites launched in 2009 to measure the gravitational field of the Earth [54].

In the recent past, satellites were characterized by a low spatial resolution and were used for several purposes over large geographic areas, but were unable to assess crop yield variability within a field [48]. Single satellite based systems continue to improve in imaging performance, including better spatial and spectral resolution as well as sensor agility, so in-track and cross-track stereo capture is available [55]. Currently, new opportunities for mapping and monitoring crop yield variability are provided by high-resolution satellite sensors (e.g., SPOT 6 and 7, Ikonos, Quick-Bird) that have narrowed the gap between image by satellite and by airborne vehicles [56,57].

Landsat series from 1 to 7 , for example, had a spatial resolution ranging from 30 to $79 \mathrm{~m}$ and a radiometric resolution of 6-8 bits, usable to some extent for mapping water quality parameters [58-61]. Landsat 8 (12-bit radiometric resolution) is suitable for remote sensing of water in lakes (even dark with CDOM-rich); although the revisit time of 16 days limits its use in routine monitoring of water body quality.

Since satellite measurements are not satisfactory for monitoring diurnal variation, Roussel et al. [62] noted advantages from the use of electromagnetic waves constantly released by the Global Navigation Satellite System (GNSS) satellite constellations for retrieving different geophysical parameters of the Earth's surface. For irrigation purposes, GNSS reflectometry (GNSS-R) system is useful for soil moisture monitoring, because it is able to monitor diurnal variation [62].

Satellite missions, labelled Sentinel 1 up to 5, were set up for environmental monitoring [63]. The launch of Sentinel-2 in 2015 opened a new era in remote sensing. This system has a medium spatial resolution, super-spectral instrument with a field of view of $290 \mathrm{~km}$, a revisit capability of 5 days (two satellites), a resolution of $10 \mathrm{~m}, 20 \mathrm{~m}$ and $60 \mathrm{~m}$, and a moderately large band set (13 spectral bands) aiming to provide global land coverage. The mission ensures continuity of the previous missions (Landsat and SPOT) and provides geochemical and physical variables, land cover maps and land change detection maps. Its image spatial resolution (from $60 \mathrm{~m}$ to $10 \mathrm{~m}$ ) allows the monitoring of several small water bodies as reported by Toming et al. [64], who have shown that Sentinel-2 was able to map water quality. It may monitor Chlorophyll a (Chl a) as an indicator of phytoplankton, Chromophoric (or colored) Dissolved Organic Materials, and Dissolved Organic Material concentrations.

Immitzer et al. [65] have assessed the suitability of Sentinel 2 data in agriculture for land cover classifications. Results appeared encouraging, although the classification results for the pixel- and 
the object-based approach were not extremely high. The authors relied on the support of two twin S2 satellites for consistently improving spectral and temporal information with high spatial resolution.

Saadi et al. [66] have conducted an experiment on regional evapotranspiration and crop water consumption estimated over an irrigated area in Tunisia with the SAMIR model that used SPOT high-resolution time series. The SAMIR model was calibrated with local evapotranspiration measurements taken from flux towers. It was validated at plot and perimeter scales using known irrigation volumes. The objective of the work was to assess the operational feasibility and accuracy of SAMIR outputs at plot and perimeter scales, in a context of high land cover complexity (i.e., trees, winter cereals, summer vegetables) and limited data available for parameterization. The authors concluded that acquisition frequency (five days) of the satellite Sentinel-2 would not answer the problem of cloudiness, even in semi-arid conditions, as in the case of Tunisia. The authors suggested the combination with Landsat8 or SPOT, which have VIS-NIR high-resolution sensors. Using these time series, including clear images approximately every 20 days, would make it possible to estimate irrigation volumes at perimeters scale. The seasonal volumes estimated by this method appeared acceptable, even though results at finer timescales (monthly and below) need to be improved.

A variety of variables (e.g., leaf chlorophyll content, leaf water content, leaf area index) are proposed for Sentinel-2 as inputs to earth system models. Van der Werff and van der Meer [63] summarized spectral position $(\lambda)$ and bandwidth $(\Delta \lambda)$, spatial resolution, heritage and purpose of Sentinel-2 bands, according to the Copernicus derived user requirements.

Escorihuela and Quintana-Seguí [67] reported recently on soil moisture measurements by remote sensing at local and regional scales. Recent technical developments have allowed the outgrowth of space borne L-band microwave radiometry. Two satellite missions, the Soil Moisture and Ocean Salinity (SMOS, 2009) and the Soil Moisture Active Passive (SMAP, 2015) provide global mapping of surface soil moisture based on radiometric measurements at L-band $(21 \mathrm{~cm}, 1.4 \mathrm{GHz})$. The authors found SMOS to be the only satellite able to detect irrigation and the only one that does not show clear vegetation or roughness effects and is able to map irrigated areas. Entekhabi et al. [68] produced composited maps of the difference between weekly mean soil moisture over one week, one month, and three months.

The NASA report "Microwave Technologies Review and Strategy" [69] contained an overview of technologies for Earth science measurements involving passive microwave radiometry for soil monitoring. The Soil Moisture Active Passive mission goal was to produce global maps of surface soil moisture at low $(36 \mathrm{~km})$ and high resolution $(9 \mathrm{~km})$. The mission was based on L-band radiometer and radar/radiometer measurements for low and high-resolution maps, respectively. The preliminary results of the Multi-Temporal Dual Channel Algorithm (MT-DCA) for retrieving (i) soil moisture; (ii) Vegetation Optical Depth; and (iii) scattering albedo estimates, from passive microwave measurements alone and without reliance of a priori information were reported. At L-band, the Vegetation Optical Depth was related to total vegetation water content and albedo to structural changes. The analysis of these two parameters, at different temporal and spatial scales, disclosed the potential of L-band microwave sensors for ecological studies on a global scale [70]. Kojima et al. [71] report an estimate of Soil Moisture Distributions across Small Farm Fields with ALOS/PALSAR. The ALOS (Advanced Land Observing Satellite) has an active microwave sensor; PALSAR (Phased Array L-band Synthetic Aperture Radar) has a fine resolution of $6.5 \mathrm{~m}$. Because of the fine resolution, PALSAR provides the possibility of estimating soil moisture distributions in small farmlands. Making such small-scale estimates has not been possible with traditional satellite remote sensing techniques.

\subsubsection{Airborne Platforms}

Airborne platforms (from $50 \mathrm{~m}$ to $50 \mathrm{~km}$ ) carry out downward or sideward sensors to obtain earth's surface images. Airborne platforms give images with a spatial resolution of $20 \mathrm{~cm}$ or less, much higher than satellite maps, but they have low coverage area and high cost per unit area. For these reasons, it is not profitable to monitor and map large areas. Airborne missions are one-time operations, 
whereas satellites provide continuous target monitoring [72]. The quality of images acquired may be degraded by factors that introduce blurring, improper focusing, atmospheric scattering and target motion $[34,40]$. The fields of application of airborne remote sensing are numerous, such as biodiversity, biogeochemical cycles, climate change, eco-hydrology, infectious disease, land use, invasive species.

For natural and agricultural environments, it is worth mentioning airborne remote sensing studies on vegetation: (i) cover amount; (ii) dominant type; (iii) canopy structure (height and Leaf Area Index); (iv) crop status; (v) canopy chemistry (nitrogen index); (vi) crop greenness; and (vii) crop health in relation to topography (elevation, slope and aspect) [73-77].

Most data seen in Google Earth, and the imagery of towns and cities, are supplied by Bluesky and DigitalGlobe, and are not taken from a satellite. On a plane or helicopter it is simple to remove/replace the old sensor with a new one that is more precise and accurate. Furthermore, it is possible to take several flights until the proper and correct image is acquired. Moreover, a plane or helicopter, different from satellites, can fly with unfavorable weather conditions (high-level clouds). Even imperfect images can undergo a post-processing stage for correcting atmospheric problems. Helicopters are usually used for low altitude applications where the ability to hover is required. Airborne hyperspectral imagery has been evaluated for estimating crop yields [78,79], green biomass [80], and crop disease [81].

In one of the first examples of application of airborne imaging to crop farming, Alvino and Zerbi [82] set up an experimental field capable of creating a continuous gradient of water table level during the rainy season. Four inclined water tables were obtained (Figure 1). Figure $1 \mathrm{~b}$ was taken in summer 1986 by an aircraft with conventional imaging equipment. Figure $1 \mathrm{c}$ is the conversion of the color photo to grayscale image, and then conversion to false colors. The upper part of the image (darker soil color) corresponds to the most drained part of the field during the winter season, which was then excluded from measurements. Results of the experiment are published by Alvino et al. [83], reporting the effect of shallow water tables on peach trees grafted on three peach seedlings.

There was was a pioneering attempt to achieve airborne RS, unfortunately not supported by knowledge appropriate to the task, and this is the main reason that the RS image was not orthogonal. The goal was to integrate ground photos of each plant with airborne images to calculate the leaf area of each tree. For this goal, several trees were fully defoliated to have an accurate measure of Leaf Area Index (LAI).

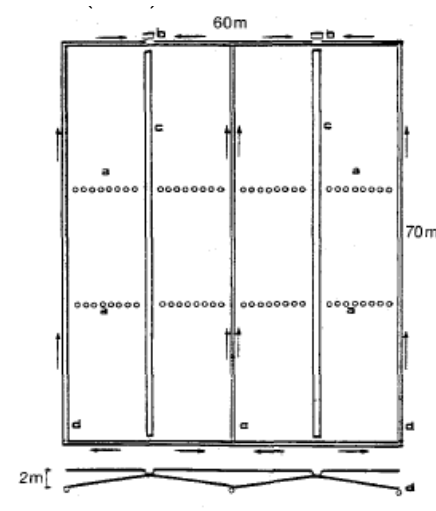

(a)

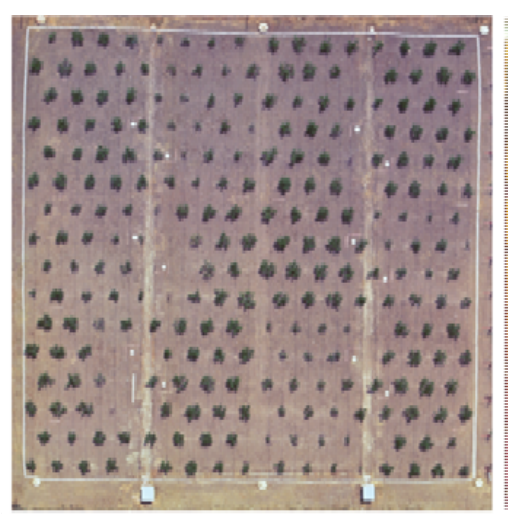

(b)

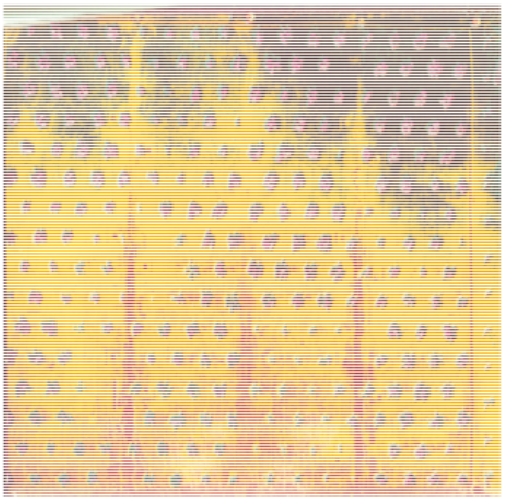

(c)

Figure 1. (a) Layout of the experimental field: (a) $a=$ observation wells; $b=$ pumping well; $c=$ water supply ditch; d= drainage ring. (b) Airborne images. (c) False color image of Figure $1 b$.

\subsubsection{UAV (Unmanned Aerial Vehicle)}

At present, unmanned airborne vehicles (UAVs) are the most common airborne platforms for civilian and military aircraft remote sensing applications [84]. 
Remote sensing with UAVs has very high resolution. It provides fast and low-cost data, and cloud cover does not prevent acquisition, so it is an important instrument for monitoring and managing crops during the growing season $[85,86]$.

UAVs come in different sizes related to their total weight. The small systems were defined as an UAV of a maximum weight of $25 \mathrm{~kg}$. Watts et al. [87], Matese et al. [51], DeBell et al. [88], Candiago et al. [89], and Toth and Jóźków [34] describe current UAS systems (fixed and rotating wing), solutions and applications. The following description provides only the basics for the UAV remote sensing field; an extended recent review (monograph) on the topic can be found in Pajeres [90], as well as in Toth and Jóźków [34].

Large volumes of UAVs are expected to fly in upcoming years, so safe operation is essential for the user and the public. There are extremely large numbers of UAV applications to remote sensing [34]. Colomina and Molina [91] reported the evolution of the use of UAVs in the field of photogrammetry and remote sensing.

Another state-of-the-art example is available in Sankaran et al. [92], who studied the use of UAV technology for various crop applications (crop emergence, vigor, characterization of yield potential). The review also reported the potential and future perspectives of using UAV imaging to evaluate the effect of biotic and abiotic stresses for crop breeding and precision crop yield management.

DeBell et al. [88] suggested that UAVs are set to become a crucial factor of a water-resource management toolkit. They can ensure high-resolution data (not available from other platforms such as satellites or aircrafts), in a cost-effective way and in a more sustainable way for water-resource targets. The authors suggest the use of UAVs for data analysis of water resource information (e.g., regular surveys of reservoir resources, soil moisture assessments by thermal imaging, more effective consumption).

An interesting point of view was reported by Anderson [53], who put an emphasis on remote and proximal sensing changes due to a variety of sensors fitted to drones and kites to improve fine-grained understanding of environmental processes. Anderson et al. [93] also proposed a grassroots remote sensing and democratic mapping for delivering rapid spatial data (GeoTIFF images) from lightweight drones and kites with open-source geospatial toolkits and android smartphone apps.

UAVs offer many advantages with respect to other platforms, the main one relying on readiness and repeatability of the measurements. The UAV operator can monitor the procedure and decide to repeat the flight if something went wrong. Conversely, each satellite has a specific revisit time (see Table 1), and it is almost impossible to replicate a survey. The airborne flights try to reduce costs by bringing together several targets and actions (e.g., one strip on different subjects or many strips on the same one). This prevents modification of the flight plan. The operation costs are the lowest for the UAVs, which are flexible and may change sensors/missions/objectives easily. However, satellite sensors cannot be replaced when they are obsolete or out of service.

\subsubsection{Ground-Based Platforms}

The more common ground-based platforms (up to $50 \mathrm{~m}$ ) are tripods, towers, poles, and cranes, as well as instruments mounted on vehicles. They are characterized by different land coverage: short (50-100 m), medium (150-250 m), and long (up to $1 \mathrm{~km}$ ). Platforms may be temporary or permanent and are usually used to support research projects, even for micro-meteorological measurements like, for example, for Bowen-ratio and Eddy-covariance [94].

Important data can be also collected in the field using vehicle-mounted instruments. O'Shaughnessy et al. [95] have studied how to enhance crop-water-use efficiency by reducing irrigation losses and enhancing soil water availability. The authors underline that abiotic and biotic factors can increase the yield gap through a reduction of water use and of crop yield potential. Emerging technologies, such as wireless communication, may be integrated with soil and plant sensors (variable-rate irrigation equipment, and decision support systems). 
Aqeel-ur-Rehman et al. [96] discussed different examples of the use of sensors and their networks for agriculture and irrigation purposes. Damas et al. [97] developed an automatic irrigation system with significant water conservation (i.e., up to 30-60\%). Evans and Bergman [98] worked on precision irrigation control of self-propelled, linear-movement and center-pivot irrigation systems, controlled by wireless technology. To improve water use efficiency, Morais et al. [99] implemented a smart irrigated system piloted by a wireless data acquisition network to acquire environmental (climate) and soil moisture data. Basu et al. [100] set a drip-irrigation-control system characterized by remote sensing data acquisition. Kim et al. [101] devised a site-specific sprinkler irrigation system equipped with a real time sensor (using Bluetooth and GPS technologies) and control software based on soil moisture, temperature and weather information data. Kim and Evans [102] and Evans et al. [103] improved the above noted irrigation system with "in-field data feedback to support the decision-making and real-time monitoring of irrigation operations via Bluetooth wireless radio communication". Thompson et al. [104] studied soil moisture sensors to support the decision-making irrigation management scheduling. The study was aimed at determining threshold values of soil water characteristics (matric potential and available soil water content), using appropriate values of leaf water potential for pepper, melon, spring tomato and winter tomato crops.

\section{Approaches to Precision Irrigation}

Remote sensing has many potential applications in many fields and at different scales. Table 2 lists field applications of remote sensing in agriculture. Moran et al. [28] summarized the important role of remote sensing in site-specific farming.

Remote Sensing can provide non-destructive, automatic, and continuous measurements, easily implemented with data transmission systems for the user to have nearly real time access to the collected data from a remote computer, smart phone or similar [30]. Most of these methods and related systems are highly sensitive and capable of working under field conditions for long periods. These characteristics confer great potential for both monitoring water stress and scheduling irrigation [105].

Table 2. Applications of remote sensing in agriculture

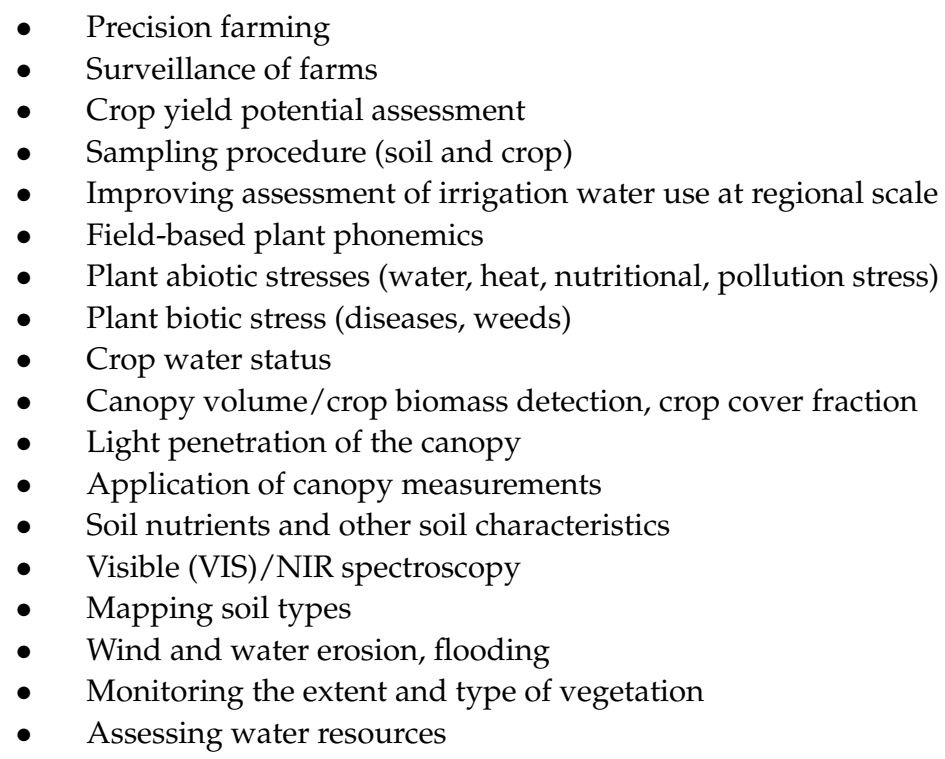

Remote sensing can provide precise information of irrigated crop areas [106] by monitoring the phenological development of crops through multi-temporal image [107]. 
Crop water status is the crucial biophysical property, used in particular to manage irrigation by remote sensing. It is, in most cases, directly associated to the available soil water content, and in other conditions to soil salt content when salinity is a limiting factor of water uptake. Similarly, plant diseases, which may be obstacles to plant-water flow, may negatively influence crop water status, which becomes an indicator of disease presence and severity $[108,109]$. Crop water status can be quantified at the canopy and leaf levels, by monitoring leaf or stem water potential, or leaf water content [110]. Unfortunately, this simplistic view is complicated by several plant factors (root signaling, aerodynamic characteristics of vegetation, genetic control of crop performance, etc.), which interact in a complicated way with environmental factors, such as solar radiation (intensity and insulation), wind speed and direction, air humidity, and air temperature. Plant species may or may not be highly coupled to the environment [111]. The $\Omega$ coefficient (or decoupling coefficient) is a measure of the coupling between conditions at the canopy surface and in the free airstream (well above the crop), and can vary between 0 (for perfect coupling) to 1 (for complete isolation). Jones [111] reports $\Omega$ values of $0.85,0.7,0.4,0.3$ for strawberry, tomato, raspberry, and citrus orchards, respectively. In other words, a citrus orchard is more coupled to the environment than more dense horticultural crops. The concept is summarized by Hsiao [112], who stated that relatively open, tall and aerodynamically rough canopies made of small leaves facilitate turbulence and air movement within the canopy, and therefore, are closely coupled to the air overhead. Conifer forests show a low decoupling factor $\Omega$. In contrast, dense, smooth and short canopies, with all the leaves packed into the limited vertical space, would obstruct air movement and therefore are nearly uncoupled from the air overhead. For many field and horticultural crops with short and dense canopies, control of transpiration may be expected to be minimal until stomata close, and canopy conductance decreases markedly. Another crucial point is the ability of some crops to limit their leaf water potential, preventing it from falling below a critical level (isohydric behavior). Marino et al. [113] have reported that daytime leaf water status (or water potential) was maintained relatively constant as long as the potential transpiration exceeded the hydraulic threshold. This means that water potential of the leaves remained relatively constant during the day and during periods of minor-to-moderate water stress events, regardless of soil water status, because of active stomatal control. The assessment of the isohydric crop response is important for crop-water-use predictions and requirements, and photosynthetic productivity under uneven irrigation conditions. In contrast, many species show unisohydric behavior with leaf water potential relatively coupled to the environment. The different behavior of isohydric and unisohydric plants may affect Remote Sensing measurements based on thermography. Two crops, one isohydric and the other unisohydric, both held in non-limiting soil water conditions, would be expected to return different values of Crop Water Stress Index (CWSI). Since both crops are well-watered, the differing behaviors of isohydric and unisohydric crops may affect irrigation scheduling if appropriate corrections are not applied to each species (e.g., by using different thermal index threshold values).

According to Casa et al [114], several methodologies are available for estimating crop water use and water use efficiency. Evett [115] developed a theoretical approach to precision irrigation based on remote sensing, considered a powerful, practical and cost-effective tool for obtaining comparable yield, crop quality, and water and nutrient use efficiencies profitably and sustainably. In the field of irrigation, five major approaches to irrigation management using remote sensing were reported (Table 3).

The five approaches can be grouped into three major categories related to ET estimation (point 1 and 4); infrared thermography (point 2 and 3) and crop characteristics (point 5). Many papers report "new methods" to calculate precision irrigation based on remote sensing, combining, simplifying or integrating the methods described above. 
Table 3. Five major approaches to irrigation management using remote sensing. From Evett [115].

1 Scheduling irrigation to replace ET estimated from a reference ET (ETo), calculated from local weather data, which is multiplied by a crop coefficient estimated with a crop coefficient function, Kc (NDVI), where NDVI is the normalized difference vegetative index (NDVI) or a similar index adjusted for reflectance from soil. The NDVI is based on canopy irradiance in the red and near-infrared bands, which can be remotely sensed.

2 Scheduling irrigation at a fixed amount of water whenever a trigger to irrigate is generated by the crop water stress index (CWSI), which is estimated using remotely sensed surface temperature $\left(T_{\mathrm{S}}\right)$ and local weather data.

3 Scheduling irrigation at a fixed amount when triggered by the time-temperature threshold index (TTTI) reaching a crop and region-specific value. The TTTI is calculated using Ts.

4 Scheduling irrigation to replace ET estimated with the field surface energy balance (FSEB), which uses remotely sensed surface temperature, Ts, determined from thermal infrared data, and data on canopy cover and surface emissivity deduced from the near-infrared (NIR) and visible bands.

5 Sensing of crop and soil characteristics in order to guide timing, placement, and amount of fertilizer and water through irrigation (or fertigation) systems of various orders of precision. The characteristics, including crop cover fraction, nitrogen status of leaves, disease, and pest damage, all of which vary spatially and temporally, are inferred from various remotely sensed vegetative indices.

Evett proposed an electronic hardware and software system that acquires data from sensors and controls the operation of other hardware to pilot irrigation. This Supervisory control and data acquisition system (SCADA) acquires in situ, remotely sensed, or near-surface remotely sensed crop, soil, and micrometeorological properties as inputs for a decision-making algorithm. The system applies defined amounts of water at defined times automatically through control of an integrated irrigation application system.

\subsection{ET Estimation}

Satellite Remote Sensing retrieval of evapotranspiration has become a popular tool and a focus of study in the past two to three decades. High-resolution daily evapotranspiration (ET) maps would greatly improve irrigation crop management [116]. Remote Sensing based ET estimation roughly started in the 1980s and has evolved into a variety of approaches and models as reported in an exhaustive paper by Zhang et al. [117]. In addition, Liou and Kar [118] reported the estimation of ET with RS and various surface-energy-balance algorithms (SEBAL). The authors reviewed these different satellites based approaches and the main physical bases and assumptions of these algorithms.

It is difficult to categorize these methods, since they try to compensate for the empirical modules and physically based modules used. Table 4 lists a classification by Courault et al. [119]

Table 4. Evapotranspiration (ET) estimation model categories. From Courault et al. [119]

\begin{tabular}{cl}
\hline 1 & Empirically direct methods (remote sensing data are introduced directly in semi-empirical models to estimate ET) \\
\hline 2 & $\begin{array}{l}\text { Residual methods of the energy budget (combining some empirical relationships and physical modules in } \\
\text { models such as SEBAL) }\end{array}$ \\
\hline 3 & $\begin{array}{l}\text { Deterministic methods (more complex models such as Soil-Vegetation-Atmosphere Transfer models (SVAT), } \\
\text { which compute the different components of energy budget (ISBA, Meso-NH) }\end{array}$ \\
\hline 4 & Vegetation-index methods (remote sensing to compute Kc or Priestley Taylor-alpha parameters). \\
\hline
\end{tabular}

Remote sensing techniques for estimating ET from satellites [120] have been developed from energy balances, thus generating estimates of actual evapotranspiration [121,122]. The University of Idaho (USA) has developed a model to estimate ET called Mapping Evapo Transpiration with high Resolution and Internalized Calibration (METRIC) [122], based on the Surface Energy Balance Algorithms from the Land (SEBAL) model of Bastiaanssen et al. [121]. In METRIC, the evapotranspiration is calculated from Landsat imagery calculating the available energy using the earth surface temperature (Ts) derived from satellite imagery thermal bands, to constrain the heat flux for one or more layers (canopy and soil), and then computing the latent heat as a residual to the surface energy balance [123]. In other words, the energy utilized by the ET process is considered as a residual of the SEBAL equation. The ratio between actual evapotranspiration ( $\mathrm{Et}_{\text {crop }}$ ) and reference evapotranspiration $\left(\mathrm{Et}_{\mathrm{o}}\right.$ ) can be calculated only when $\mathrm{ET}$ is measured; this ratio is the $\mathrm{Kc}_{\mathrm{cact}}$, namely 
the actual crop coefficient [124]. Allen et al. [122] reported this method (Crop ET estimations based on $\mathrm{K}_{\mathrm{cact}}$ ) is a useful tool for field and regional water management.

The energy-balance approach has the benefit that it can be utilized to quantify the dimensions of irrigated fields and their water-use dynamics, without reference to source of water as opposed to a water balance model. This latter model necessitates the information of both the magnitude and temporal distribution of rainfall and irrigation applied to fields [125]. Temperature-based methods, as SEBAL, can be automated and likely outperform vegetation-based methods in irrigated areas, especially under conditions of low vegetation cover and high soil evaporation. According to Biggs et al. [126], an automated SEBAL can estimate the evaporative fraction from irrigated crops with a mean error of $14 \%$ of Rn (range $218 \%$ to $124 \%$ ). Allen et al. [127] confirmed the maturing technology of SEBAL and METRIC for deriving a satellite-driven surface energy balance for estimating ET from the ground's surface. The authors foresee a great future for these models in the scientific groups dealing with water resources.

Santos et al. [120] have combined METRIC-derived estimates of ET with a water balance model named LORMOD [128] to evaluate, at a plot level, the use of near-real time ET estimates to update and correct irrigation scheduling predictions and to assess its impact on WUE. ET estimates derived from satellites were used in a daily soil-water-balance model to improve accuracy of field-by-field ET demands and, as a consequence, field-scale irrigation schedules. This approach combined high spatial resolution (satellite RS) data with high temporal resolution data (daily soil-water-balance), providing significant advances in irrigation schedules, as reported for cotton (a $24 \%$ reduction) increasing field irrigation efficiency to 0.72; the field irrigation efficiency reached 0.90 for sugar beet [120].

Trezza et al. [129] reported an estimation of actual ET for central New Mexico. They matched ET images derived from MODIS with those taken by Landsat. The adoption of a METRIC model based on MODIS imageries produced monthly and annual ET estimates, comparable to those obtained with Landsat imagery.

Elhaddad and Garcia [130] reported a ReSET model based on wind from multiple weather stations and the use of a weather station for the model calibration. This flexible approach generated raster interpolated weather parameters, accounting for spatial variation of weather parameters between weather stations, which can be significant. They found that ET calculated using this approach could vary by $17 \%$ compared with ET calculated with point values.

Subsequently, Elhaddad and Garcia [131] assessed the use of actual ET calculated by ReSET to estimate seasonal crop water use at regional scale instead of the traditional ET estimation method based on reference ET and crop coefficients.

Ortega-Farías et al. [132] estimated the energy balance components over a drip-irrigated olive orchard, using thermal and multispectral cameras placed on a helicopter-based unmanned aerial vehicle, acquiring high-resolution images to assess intra-field spatial variability.

In the field of irrigation scheduling/WUE, there are very few concrete outcomes. In particular, D'Urso et al. [133] analyzed, from the PLEIADeS framework, five agricultural systems, in a broad range of arid and semi-arid conditions characteristic for the European, Southern Mediterranean, and American regions. The aim of the project was to improve the efficiency of the irrigation schemes, made possible through wide space-time coverage of Earth Observation data and interactive networking capabilities of Information and Communication Technologies. They included the following: canopy parameters, fractional vegetation cover, LAI, albedo, crop coefficients, potential ET, irrigation water requirements. They confirmed the possibility of estimating crop coefficient from NDVI, relying upon advances in spatial and radiometric accuracy of new sensors (e.g., Sentinel-2), for a full exploitation of their applications.

Peña-Arancibia et al. [107] quantified irrigation water use and water provenance (surface water or groundwater), combining t remote sensing data on irrigation dynamics and actual ET linked with a river-reach hydrological model. They concluded that the results were as accurate as those of more traditional irrigation area modelling using remotely sensed irrigated areas. Actual ET data can be used 
to understand irrigation dynamics, the constraints in irrigation models, and specific areas that require better monitoring.

Vanino et al. [134] estimated the ET and crop coefficients of table grape vineyards trained on overhead "tendone" systems in the Apulia region (Italy). The FAO direct methodology for estimating potential evapotranspiration (ETp) was used to estimate maximum vineyard transpiration. The model, based on existing validated methodologies, used appropriate values of canopy variables (albedo and the LAI) derived by means of multispectral satellite data. ETp values (mean seasonal daily ET) ranged between 4.2 and $4.1 \mathrm{~mm} \cdot \mathrm{d}^{-1}$, and from 0.88 to 0.93 in 2013 and 1.02 to 1.04 in 2014 for the midseason values, respectively. The results indicated that the values of Kc are site- and year-specific and depend on local $\mathrm{ET}_{0}$ rates, rainfall frequency, cumulative thermal requirements, and effective canopy cover. The resulting crop water requirements were lower than the actual average irrigation volumes applied by farmers, thus suggesting the possibility of improving the water use efficiency of these crops by adopting the proposed methodology. We agree with the authors that, in the Mediterranean, few studies have investigated the satellite Kc estimation for vineyards.

López-López et al. [135] estimated ET starting from field weather data and Kc estimated with a function related to vegetation indices such as NDVI or index adjusted for reflectance from soil.

Kamble et al. [136] studied how to estimate Kc directly from reflectance and VIs derived from a satellite. The authors found that NDVI- $\mathrm{K}_{\mathrm{c}}$ quantified from remote sensing could be useful for estimating WUE, irrigation scheduling and performance, and agricultural water budgets. The NDVI- $\mathrm{K}_{\mathrm{c}}$ may be also utilized for agriculture water conservation, starting from local to continental scales.

Recently, Battista et al. [137] published a paper with the aim of demonstrating how spatialized meteorological data and remote sensing techniques may allow one to estimate actual ET and the soil water content of a small plot (about 0.1 ha) of an olive orchard. As a rule, for Mediterranean areas, trees were covered by several herbaceous species. The authors found that the NDVI-Cws (coefficient of water stress) method is a suitable tool for estimating daily olive tree actual transpiration and soil water content in complex and multi-layer Mediterranean agricultural ecosystems. The novelty of the adopted method was to consider the spatially fragmented, two-layer structure of an olive orchard. For instance, the ETa of trees and grasses were combined with weather data (precipitation) to assess the site-specific water balance, which was assessed through comparison with daily measurements of soil water content. Moreover, this highlighted the importance of separating trees and grasses for estimation of the NDVI, adopting statistical operations to satellite imagery with different spatio-temporal properties.

Marshall et al. [138], with the aim of partitioning ET into soil evaporation and crop transpiration, studied the ratio-based vegetation indices (NDVI, SAVI, EVI) retrieved from optical remote sensing, highlighting their limitations and how VIs can induce large model error. NDVI explained half of the variability in transpiration, the largest component of ET. However, to estimate total ET one should consider the Photochemical Reflectance Index (PRI). To estimate soil evaporation, the authors suggest two new ratio-based indices derived from NIR bands 743 and $953 \mathrm{~nm}$ and visible blue $428 \mathrm{~nm}$ and from SWIR1 bands $1518 \mathrm{~nm}$.

González-Dugo and Mateos [139] used an approach based on the conjecture that variations in the size of the crop have much stronger effects on its ET than variations in stomatal conductance. This assumption seems to be valid for irrigated crops, according to several studies [140-142]. The results showed the potential of this method for field application. Since there is little agreement on the nature of the relationships between VIs and Kc, the latter can be estimated from spectral measurements. The rationale is that both the component of the crop coefficient that represents transpiration $(K \mathrm{cb})$ and VIs are sensitive to crop biomass (LAI and ground cover fraction- $-f_{c}$ ). The relationships between $K \mathrm{cb}$ and VIs could be linear or non-linear. The linearity of these relationships depends on the crop architecture [143]. Er-Raki et al. [142] used the same approach to derive Kcb values of wheat crops, analyzing the relationships between VIs, and both LAI and fc.

The use of remotely-sensed-vegetation indices has been tested to predict crop coefficients at different scales. In fact, González-Dugo and Mateos [139] found that the NDVI and SAVI were strictly 
related to LAI, vegetation ground cover and biomass. These relationships were obtained by radiometric measurements obtained from satellite and ground-based platforms. The relationship is simple and robust and may be used for studying WUE and water productivity at a regional level.

The statistical analyses of field data and remote sensing data, derived from multispectral imagery using an UAV, confirms the feasibility of applying the proposed methods to assess physiological and structural properties of Citrus under water and saline stress. The novelty of this study was to show that diurnal changes in physiological and structural traits of citrus irrigated with RW combined with RDI could be determined by multispectral images from UAVs. NIR was a useful indicator of s, A and $\mathrm{g}_{\mathrm{s}}$ on both crops. The NDVI was strictly related to gas exchange in both species and on mandarin [144].

Zarco-Tejada et al. [145] hypothesized that the index PRI (normalized by canopy chlorophyll content), might be a strong indicator of the diurnal dynamics of water stress. They acquired narrow-band multispectral and thermal imageries over a vineyard cultivated under three different irrigation treatments, and evaluated the relationships between the normalized PRI, field-physiological parameters (stomatal conductance) and plant water potential. Relationships with CWSI, which were used as a remote sensing benchmark for water stress detection, were also discussed by the authors, who reasoned that CWSI can be used as a remote sensing benchmark for water stress detection. Some critical points were suggested for integrating VIs derived by UAVs and everyday water resource management, such as the integration of differential global positioning and the development of intelligent control of UAV platforms to improve positional accuracy and spatial data capture.

A review by Kang et al. [146] set up the first worldwide dataset to analyze the global LAI-VI relationships at different spatial and temporal scales. Analysis was derived from low-resolution $(30 \mathrm{~m})$ satellite Landsat images, with the goal of producing large-scale fine resolution LAI maps, essential for agricultural applications, especially in mosaic agriculture. The authors reported that the LAI-VI relationships were crop-specific and may explain why the largest amount of variance in field-measured LAI was obtained using only remotely sensed observations.

\subsection{Infrared Thermography}

\subsubsection{CWSI}

Scientists tried to find indexes that describe the relationship between and thermal characteristics of plants and water stress [147]. Jackson et al. [148] set up the CWSI, Jackson [149] the Surface Temperature (ST), Moran et al. [150] the Water Deficit Index (WDI), Vidal et al. [151] the Stress Index (SI), and Guilioni et al. [152] the Stomatal conductance index. Plants showing symptoms of wilting emit more longwave infrared radiation, revealing canopy temperature. Unfortunately, canopy temperature is affected by meteorological conditions at the time of measurement, so it cannot be an absolute indicator of water stress.

We recommend several papers related to theoretical approaches dealing with infrared thermography: Jones and Vaughan [40] provided a rigorous and detailed explanation of the theory and practical applications of remote sensing; Maes and Steppe [153] wrote an exhaustive review on thermal remote sensing technique and field variation of plants and environmental parameters involved. Other key papers include those from Mulla [94], Gago et al. [154], Thenkabail et al. [155], and Jones [156].

Among the indexes cited above, the most studied is the CWSI, which was developed at the U.S. Water Conservation Laboratory in the 1970s and 1980s [148,157,158] and has been commercialized and widely used in irrigation management. Jackson et al. [148] found that CWSI was defined by the ratio of actual to potential ET calculated from the Penman-Monteith equation, and highlighted the usefulness and limitation of the index. Although it appeared to be a promising tool for quantifying crop water stress, it was unable to quantify crop water needs, or the time threshold for watering a crop.

A long list of indices is available at the website IDB (http://www.indexdatabase.de/db/i. php?offset=1), which reports the basic information for each index including the following: name, 
abbreviation, formula, variables, explanations of variables, wavelengths, source, description; sensors, visualization of required spectral range; visualization of Sensor-Bands, applications, references. Given defined environmental conditions (air humidity, air temperature), the CWSI index is based on the quantification of the behaviour of a crop both when it is fully transpiring and when it is not. López-López et al. [135] expressed CWSI in terms of evapotranspiration:

$$
\mathrm{CWSI}=1-\mathrm{ET}_{\mathrm{c}} / \mathrm{ET}_{0}
$$

where, $\mathrm{ET}_{\mathrm{c}}$ is the actual crop evapotranspiration and $\mathrm{ET}_{0}$ is the reference evapotranspiration. According to López-López [135], the relation between $\mathrm{ET}_{\mathrm{c}}$ and $\mathrm{ET}_{0}$ approaches the theoretical values proposed by Jackson [148], because it is decoupled from the wind velocity as in the classical form, according to Idso et al. [158].

Idso [159] suggested replacing the estimations of VPD from minimum temperature with air temperature measurements in direct radiation on irrigated plots, with the goal of increasing and partly correcting the influence of the superficial soil temperature on LAI. The accurate assessment of the ET by means of the CWSI is assumed by the relation between $\mathrm{ET}_{\mathrm{C}}$ and the leaf's water potential $\left(\mathrm{ET}_{0}\right)$ at dawn, according to Itier et al. [160].

Evett [115] defined the CWSI as:

$$
\text { CWSI }=\left(\left(\mathrm{T}_{\mathrm{c}}-\mathrm{T}_{\mathrm{a}}\right)_{\mathrm{m}}-\left(\mathrm{T}_{\mathrm{c}}-\mathrm{T}_{\mathrm{a}}\right)_{1}\right) /\left(\left(\mathrm{T}_{\mathrm{c}}-\mathrm{T}_{\mathrm{a}}\right)_{\mathrm{u}}-\left(\mathrm{T}_{\mathrm{c}}-\mathrm{T}_{\mathrm{a}}\right)_{1}\right)
$$

It uses the crop canopy temperature (measured by an IR thermometer or thermal images) and environmental parameters (air temperature, air humidity, wind speed, solar radiation). The canopy-air temperature difference $\left(T_{c}-T_{a}\right)$ is normalized to the lower and upper limits of canopy-air temperature differences, which represent non-water-stressed and completely water-stressed crops, respectively. The subscript " $\mathrm{m}$ " denotes measured data, while " 1 " denotes a lower baseline (non-water-stressed crop), " $u$ " denotes an upper limit (completely water stressed crop), which is an estimated parameter. The $\left(T_{c}-T_{a}\right)_{1}$ and $\left(T_{c}-T_{a}\right)_{u}$ limits may be estimated either on an empirical or theoretical basis as described by Idso et al. [158] and Jackson et al. [148]. Both approaches require readings of air humidity and air temperature but it works better with wind speed and solar radiation data, and estimates of bulk canopy resistances.

Irrigation scheduling based on $\left(\mathrm{T}_{\mathrm{c}}-\mathrm{T}_{\mathrm{a}}\right)$ has often been determined by the stress degree day method (SDD), originally suggested by Idso et al. [157] and Jackson [161]:

$$
S D D=\sum_{i=l}^{n}\left(\mathrm{~T}_{\mathrm{c}}-\mathrm{T}_{\mathrm{a}}\right) \mathrm{i}
$$

with $T_{c}$ and $T_{a}$ measured 1-1.5 h after solar noon at day i, during a n-day period. Irrigation was initiated as soon as SDD exceeded 0 . The formula was used successfully for different crops [162], and according to Maes and Steppe [153] SDD worked well for wheat, and in semi-arid climates where weather conditions were expected to differ little between consecutive days.

According to King and Shellie [163], the CWSI is also defined as:

$$
\text { CWSI }=\left(\mathrm{T}_{\text {canopy }}-\mathrm{T}_{\mathrm{nws}}\right) /\left(\mathrm{T}_{\mathrm{dry}}-\mathrm{T}_{\mathrm{nws}}\right)
$$

where $T_{\text {canopy }}$ is the temperature of fully sunlit canopy leaves $\left({ }^{\circ} \mathrm{C}\right), \mathrm{T}_{\mathrm{nws}}$ is the temperature of fully sunlit canopy leaves $\left({ }^{\circ} \mathrm{C}\right.$ ) when the crop is non-water-stressed (well-watered) and $\mathrm{T}_{\mathrm{dry}}$ is the temperature of fully sunlit canopy leaves $\left({ }^{\circ} \mathrm{C}\right)$ when the crop is severely water stressed due to low soil water availability. Temperatures $\mathrm{T}_{\mathrm{nws}}$ and $\mathrm{T}_{\mathrm{dry}}$ are the lower and upper baselines used to normalize CWSI for the effects of environmental conditions (air temperature, relative humidity, radiation, wind speed, etc.) on $\mathrm{T}_{\text {canopy }}$. Maes and Steppe [153] emphasized the limited application of the CWSI by the difficulty of estimating without actually measuring $T_{n w s}$ and $T_{d r y}$. 
Jones [164] proposed a stress index (SI $\mathrm{SWSI}_{\mathrm{CWI}}$ ) analogous to the Idso-Jackson CWSI, using wet surface conductance rather than the finite value for a well-watered crop.

$$
\mathrm{SI}_{\mathrm{cwsi}}=\left(\mathrm{T}_{\text {leaf }}-\mathrm{T}_{\mathrm{wet}}\right) /\left(\mathrm{T}_{\mathrm{dry}}-\mathrm{T}_{\mathrm{wet}}\right)
$$

Rojo et al. [165] suggested a modified CWSI (MCWSI) in grape and almond using the continuous leaf monitor data, where the well-watered and dry conditions were measured using a well-watered tree and a simulated dry leaf. The CWSI and MCWSI indices were calculated and were capable of representing the stress level of the grape and almond crops, so variable rate irrigation was implemented.

The CWSI is considered a sensitive tool for monitoring and assessing plant water stress for a wide range of crops. CWSI was inversely correlated to cotton yields [166], and positively correlated with soil water depletion for a fully developed canopy when no soil reflectance was present [167]. The CWSI was also able to foresee a yield of several crops under stress and to develop schemes for managing irrigation $[168,169]$. Furthermore, the Water Deficit Index, which is a two-dimensional CWSI normalized for vegetation cover, was related to crop water stress [150,170].

Orta et al. [171] studied the upper and lower baselines, and CWSI values on watermelon were slightly different. They tested CWSI for scheduling irrigation for watermelon grown with five irrigation treatments $(0 \%, 25 \%, 50 \%, 75 \%$, and $100 \%)$ in terms of the replenishment of the water depletion $(0.90 \mathrm{~m}$ soil profile depth). The CWSI was calculated from IR canopy temperatures, air temperatures, and vapor pressure deficit values. In two years, the fully irrigated treatment gave the highest yield and water use. The CWSI values tended to be consistent with the soil water content. The authors proposed a linear equation of CWSI versus yield prediction, and suggested testing in long-term experiments a critical value of CWSI at which a farmer should irrigate.

Recently, Bellvert et al. [172] measured the CWSI in three peach cultivars (Prunus persica L.) throughout different growing seasons. They measured the canopy temperature of well-watered trees using high-resolution thermal imagery obtained from an airborne platform and related it to leaf water potential $\left(\psi_{\mathrm{L}}\right)$ as a water stress indicator. Results demonstrated that (i) the CWSI had similar seasonal responses and (ii) a common "non-water-stressed baseline" can be used during the course of the entire crop season. The CWSI is a practical method for evaluating the spatial variability of peach tree water status in heterogeneous orchards, and for deriving $\psi_{\mathrm{L}}$ maps throughout a complete growing season.

Santesteban et al. [173] evaluated the ability of high-resolution UAV-based thermal imaging to estimate instantaneous and seasonal variability of plant water status within a vineyard. CWSI correlated well with $\psi s$ and $g_{s}$ at the moment of image acquisition, showing great potential for monitoring instantaneous variations in water status, but it did not provide a good estimation of variations of plant water status on a single day. The results added evidence regarding the suitability of this approach, and reinforced the potential role UAV thermal imaging may have as an instantaneous water-stress mapping tool. Similarly, Baluja et al. [174] conducted an airborne study over a vineyard, with the goal of computing image-derived spectral and thermal indices, and indicators of water status in vines including (i) the crop water stress index (CWSI), stomatal conductance index (Ig) [164] and (ii) a formulation of the stomatal conductance index (I3) [164]. They concluded that the relationship between thermal imagery and derived indices can be considered as a short-term response, a kind of instantaneous "picture" of the plant water status situation, while spectral vegetation indices are probably the result of cumulative water deficits.

Berni et al. [84] validated a methodology for producing high-resolution maps of canopy conductance and CWSI, potentially useful for calculating actual ET and as an input for scheduling irrigation. The canopy of conductance and CWSI maps of olive orchards were acquired by airborne and UAV platforms for two years with different irrigation treatments.

Testi et al. [175] showed that the CWSI measured in the first afternoon hours were a good tool for identifying seasonal changes in the water status of a pistachio orchard submitted to variable 
water stress by regulated deficit irrigation practices. The temperature of pistachio trees showed great responsiveness to variations in plant water status.

López-López et al. [135] analyzed ET and CWSI in tomato confirming that the use of infrared thermometry to calculate the CWSI is a reliable technique for scheduling irrigation using the determined upper and lower CWSI baselines in a husk tomato crop. The CWSI value increased until it reached 0.7 in the treatment with severe irrigation restrictions $\left(40 \% \mathrm{ET}_{\mathrm{o}}\right)$.

González-Dugo et al. [176] used UAV systems to derive CWSI from high-resolution thermal imagery. They assessed the spatial variability of crop water status in a pistachio orchard for precision irrigation purposes. The authors estimated a possible reduction of irrigation costs moving from common irrigation system to a variable rate irrigation system [177].

González-Dugo et al. [178] also used IR imagery taken by UAVs to evaluate the variability in the water status of five fruit tree species. They compared the daily differential between $T_{c}-T_{a}$ (canopy and air temperature) with the tree water status. Since the slope of the differential with time was highly correlated with water status, the authors proposed the slope as an indicator of the stomatal behavior. An empirical approach was used to define the upper and lower limits of $T_{c}-T_{a} ; C W S I$ was calculated using the temperature data from a 13-h flight. Another important contribution of the paper was the assessment of variability in the water status based on the differences in relative canopy temperatures. The authors concluded that their approach (i) was worthwhile for managing precision irrigation; (ii) could identify water stressed areas; and (iii) could define threshold CWSI values, a great help for farmers and for irrigation strategies at different phenological stages.

Sezen et al. [179] analyzed the CWSI of red pepper irrigated with two systems (drip and furrow) and with different irrigation regimes. The authors concluded that CWSI could measure crop water status and improve irrigation scheduling. For high-quality yields, the authors suggested CSWI values of 0.26 for drip irrigation and 0.38 for furrow irrigation. For both irrigation methods, linear relations were found between CWSI and red pepper yield.

Agam et al. [180] tested CWSI for analyzing the changes in water status of olive trees when entering into and recovering from stress on a diurnal scale. CWSI was tested in an empirical form and in two analytical configurations. The results showed that the empirical CWSI was capable even given its limitations, while the analytical forms of CWSI needed enhancement for monitoring the water status of olive. The authors proposed calculating the wet temperature analytically and fixing the dry temperature at a level of $5{ }^{\circ} \mathrm{C}$ higher than the air temperature. Thermal imaging and water status measurements were recorded between 12:00 and 14:00.

Wang et al. [181] conducted a two-year experiment on early-ripening peach exposed to postharvest deficit irrigation schemes, concluding that IR measurements might estimate plant water stress, particularly in high-radiative arid and semi-arid climates. They found that the temperature differences (infrared-canopy temperature and air temperature) where correlated to stem water potential and proved to be a useful tool for water stress assessment for managing regulated deficit irrigation. Temperature differences (midday canopy to air temperature) ranged from 5 to $7^{\circ} \mathrm{C}$ in the water-stressed postharvest deficit irrigation treatments, while they ranged from 1.4 to $2{ }^{\circ} \mathrm{C}$ in the non-water-stressed control treatments.

Taghvaeian et al. [182] calculated CWSI for four 1-hour periods, ranging from 10:00 to 14:00, each day for 29 days. The estimated CWSI was smallest from 10:00 to 11:00 and largest from 12:00 to 13:00. These values may be used for precise (amounts and timing) irrigation scheduling. When measurements were taken during earlier hours, the authors suggested adopting a conservative threshold value of CWSI; in contrast, they suggested higher levels when measurements were recorded one hour after solar noon.

García-Tejero et al. [183] conducted a study using thermal data to monitor crop-water status in irrigated Mediterranean viticulture. They found that CWSI and IG might provide more meaningful information about the crop-water status than $\mathrm{T}_{\text {canopy-air. }}$. The authors also found that $\mathrm{T}_{\mathrm{C}}$ was 
significantly correlated with $\mathrm{g}_{\mathrm{s}}$ and net assimilation, suggesting that it can be used as a simpler parameter to support thermal remote sensing of water stress in grapevines.

Kullber et al. [184] compared and evaluated the accuracy of several water-stress coefficient methods for estimating crop $\mathrm{ET}_{\mathrm{c}}$ under different levels of deficit irrigation. Four canopy temperature based methods were used to calculate Ks: CWSI, Canopy Temperature Ratio ( $T_{C}$ ratio), Degrees Above Non-Stressed Temperature (DANS), Degrees Above Canopy Threshold (DACT). Methods using only canopy temperature measurements (DANS, DACT, and Tc ratio) performed with comparable error to more data intensive methods such as CWSI and demonstrated their potential for irrigation scheduling.

Osroosh et al. [185] carried out an experiment on apple trees, to compare two empirical indexes, a CWSId (averaged over daylight hours) and a CWSIm (midday CWSI). Since CWSI was very sensitive to mild variations in the soil water content, the authors suggested using CWSId and CWSIm for estimating soil water availability. These indices were also stable under transitional weather conditions.

Mangus et al. [186] considered the time changes of IR for monitoring corn water stress at high spatial and temporal resolution for managing irrigation water within large agricultural production systems. In the 80-day study, they observed a statistical decrease in soil moisture "only when the CWSI value increased past 0.6 with $82 \%$ of soil moisture variation explained by the CWSI". The CWSI was negatively correlated to soil moisture, demonstrating the potentiality of CWSI (i) as an alternate irrigation scheduling method; and (ii) for quantifying spatial soil moisture by IR canopy temperatures.

\subsubsection{Time-Temperature Threshold (TTT)}

The TTT is a method based on a canopy temperature threshold and a time threshold $[187,188]$. Because it is a response method of automatic control, the TTT method does not need supplementary inputs for activating irrigation; and it has been credited for regulating water-use efficiency. Evett et al. [188] found no statistical differences in yield and WUE, when comparing TTT and with manually irrigated plots, in soybean and corn.

O'Shaughnessy et al. [189] studied the relationship between cotton irrigation scheduling, using soil water measurements and two thermal indices. An automatic irrigation scheduling determined by a TTT algorithm reduced applied water volumes that did not negatively affect yield. In well-watered conditions (full irrigation), the TTT method increased WUE with respect to the water balance method; differences were not significant at reduced water depths (rates of 33 and $67 \%$ of full irrigation). The authors also found similar trends between two thermal indices, although the daily theoretical CWSI resulted in over-irrigation when it was over 0.5.

Lamm et al. [190] compared the TTT and ET-based irrigation scheduling for corn production. The TTT method accumulated time when the crop was above a specified temperature. An irrigation event signal was triggered when the accumulated time exceeded the specified TTT threshold. The authors compared (i) three irrigation treatments with TTT values of $2.5 \mathrm{~h}, 4.0 \mathrm{~h}$ or $5.5 \mathrm{~h}$ above a canopy temperature of $28^{\circ} \mathrm{C}$; and (ii) two $\mathrm{ET}_{\mathrm{c}}$ treatments $(100 \%$ and $65 \%)$, plus a treatment receiving no further irrigation after mid-July in Kansas. The results indicated that a TTT with a threshold of $2.5 \mathrm{~h}$ corresponded to a fully irrigated treatment.

O'Shaughnessy et al. [191] developed a method of integrating the CWSI over a day for presenting clear CWSI signals occurring in some environmental conditions, near solar noon. CWSI-TT was the accumulated time when CWSI was greater than a threshold value of 0.45 ; this cumulated time value was compared with a CWSI-TT value obtained for a well-watered crop. The use of CWIS-TT, however, can lead to an over-irrigation due to false positive triggers that may be generated early in the season. CWSI-TT provided yield results similar to scientific irrigation scheduling using a neutron probe.

Osroosh et al. [192] tested an automatic control system along with a wireless network of soil, thermal and weather sensors, developed for an apple orchard. Seven irrigation-scheduling algorithms were tested: TTT, CWSI, soil-based using granular matrix sensors (SOIL), an ET model, a soil water balance (WB), a combination of SOIL and $\mathrm{WB}$, a conventional irrigation practice used in the region, and soil-based using a neutron probe (NP) as benchmark. The treatments TTT, CWSI, NP and WB 
substantially reduced water $(70 \%)$ while maintaining $\psi_{\text {stem }}$ within the non-stressed range. WB seemed to demonstrate the characteristics of being economical, easy to implement and accurate.

DeJonge et al. [193] conducted an experiment on corn to evaluate several water stress indices based on canopy temperature. All thermal indices responded quickly to irrigation-treatment differences at major growth stages, in particular Degrees Above Non-Stressed index and Degrees Above Canopy Threshold index were highly correlated with CWSI above the corn threshold of $28^{\circ} \mathrm{C}$ used in the TTT method. Furthermore, all indices showed a linear relationship with soil water deficit at high temperatures. Degrees Above Canopy Threshold was the best index due to (i) the strong relationships with other indices and crop water measurements; and (ii) because it was derived from a single canopy temperature measurement.

\subsubsection{Thermography Issue and Critical Aspects}

The infrared thermometry measurements suffer from several critical points, which may affect negatively the accuracy of the results. Jones et al. [156] found many important deficiencies in the general applications of CWSI. In particular deficiencies included (i) the absolute temperature ranges may be small in humid environments; (ii) the canopy temperature was negatively affected when crop surface target accidentally includes areas such as soil, sky, and trunks; (iii) there existed a different distribution of temperatures of sunlit and shaded parts of the canopy; and (iv) the sunlit part of the canopy showed a wider range of temperatures when viewed normal to the rows or down the rows.

Evett et al. [115] reported some other critical points including that (i) the signal was not stable during cloudy periods; (ii) the lower base line and upper limit were difficulty to determine and (iii) no uniqueness of these limits. Others problems were related to the first growth stages, when soil background was visible and it was more difficult to measure the canopy temperature.

\section{Baselines}

The theoretical definition of the two baselines, the lower baseline (well-watered crop, or more precisely non-water-stressed crop), and the upper baseline (completely water stressed crop).

The lower baseline (non-water-stressed crop) depends on the plant species, and even among varieties of the same species, which have different canopy and leaf structures. The energy balance of crops may differ consistently, since each canopy structure has its own radiometric properties, which can facilitate in some cases eradiation capture, and, in other cases, that which can escape excessive radiation loads.

\section{Leaf Temperature Variability}

Optical parameters of leaves of 30 plant species were presented by Gausman and Allen [194], demonstrating that each species demonstrated its own coefficient of leaf emissivity. Leaves showed wide ranges of temperature within a crop, often several degrees within and between plants because of several factors. Each plant had (i) specific leaf angles, that may vary during the day for several reasons (e.g., leaf turgidity; radiation load, etc.); (ii) specific dimensions of (young and old) leaves, (iii) unique canopy architecture, (iv) different LAI, (v) different radiation loads that impacted the crop, and (vi) aerodynamic properties related to the wind speed and direction. Therefore, Jones et al. [195] stated that "is desirable to measure the canopy surface temperature $\left(T_{c}\right)$ as an aggregate of all leaf temperatures". Maes and Steppe [153] noted that measurements of $\mathrm{T}_{\mathrm{c}}$ differed from those of a single leaf for two main reasons. Canopy emissivity was larger than leaf emissivity, which has the function of capturing radiation for photosynthesis. The estimation of canopy emissivity is quite difficult because it requires night measurements. A second difference with canopy temperature measurements include branches and, in particular, soil which have temperatures usually higher than the canopy. This is particularly evident in orchards and croplands when the canopy cover (crop fraction) is low. Furthermore, they reported that in stressed conditions, at very low leaf stomatal conductance, the total range in surface temperature between leaves is larger than in unstressed conditions, so that canopy temperature variability often 
reported as an index of drought stress. The sunlit side of a crop tends to have a greater variance of temperature among leaves than the shade side.

Sunlit and Shade Leaves

Both baselines account for fully sunlit canopy leaves, but it is evident that the average canopy temperature is a summary of attributes of different leaves, an extensive variety of leaf temperatures, with sunlit leaves showing much higher temperatures than shaded leaves $[156,196]$. Both shade and sunlit leaves constantly move to adjust light interception to maximize their water use efficiency and protect leaves from excessive heat and radiation load. In both well-watered transpiring and water-stressed canopies, there will be a wide range of sunlit and shaded leaves, since it is known that that dry matter accumulation in crops is directly related to the interception of solar radiation, up to the critical LAI.

Alvino et al. [196] reported that the fraction of light absorbed by leaves, which controls crop growth rate, plant development, crop biomass accumulation, is directly related to the interception of solar radiation, up to the critical LAI [197]. The light distribution within the canopy affects, inter alia, the photosynthetic efficiency. Under comparable environmental conditions, the most important are the light levels, since leaf photosynthetic rates decline with age after leaf full expansion. The complexity is made worse by the difficulty of estimating the true age of each leaf in a plant community. Furthermore, the head-on viewing of a crop may increase the number of leaves that appear shaded, even though they are sunlit. As reported by Jones [156], "there are always a few sunlit leaves on the shaded side and some shaded leaves visible on the sunlit side".

Testi et al. [175] reported that measurements of tall trees are particularly challenging, because (i) open sky is within the sensor field of view; (ii) a tree canopy has a vertical rather than horizontal structure; and (iii) there is a canopy temperature difference between the shaded and the sunlit sides. Crops with genetic modifications (reduced leaf and modified stipule morphology) may result in enhanced yield when water is a limiting factor, avoiding drought stress [198].

It is still critical to define a well-watered crop, which according to definition should transpire at a rate regulated by physical conditions (e.g., VPD), and not present any physical resistance to transpiration fluxes. However, even well-watered plants show a midday depression of stomatal conductance in case of high VPD [199]. Different indices and procedures have been proposed [108,111,115,153,164,200].

As correctly stated by King and Shellie [163], the CWSI has not been widely used for irrigated crops since it is necessary to acquire the temperature difference of both transpiring and non-transpiring leaves under the same environmental conditions. Stated below King and Shellie [163] obtained CWSI values ranging from 0 to 1 , when adopting the $T_{\text {air }}+5{ }^{\circ} \mathrm{C}$ for estimating the temperature of non-transpiring leaves $\left(\mathrm{T}_{\mathrm{dry}}\right)$, as proposed by Irmak et al. [201] and Möller et al. [108] for corn and grape, respectively. The authors found that the maximum temperature difference between the canopy of deficit-irrigated vines and $\mathrm{T}_{\text {air }}$ was influenced by irrigation frequency. Greater maximum temperature differences were found for vines irrigated once a week compared to those irrigated three times per week. The cultivar response to deficit irrigation was different with 'Syrah' vines, which were 2-4 ${ }^{\circ} \mathrm{C}$ cooler than 'Malbec' vines [202], and differences were also detected in leaf surface temperature among grapevine cultivars undergoing water stress. Bellvert et al. [202] reported $\mathrm{T}_{\mathrm{nws}}-\mathrm{T}_{\text {air }}$ values more than $7.5^{\circ} \mathrm{C}$ for 'Pinot-noir' vines subject to water stress, when air temperature was $32.3^{\circ} \mathrm{C}$ and air humidity $2.37 \mathrm{kPa}$. In more stressful conditions $\left(37^{\circ} \mathrm{C}\right.$ and very low air humidity), the authors measured a difference of $13^{\circ} \mathrm{C}$ in 'Syrah' and $17^{\circ} \mathrm{C}$ in 'Malbec' $\left(\mathrm{T}_{n w s}-\mathrm{T}_{\text {air }}\right)$. King and Shellie [163] report that a difference between canopy and air temperature of vines of about $17^{\circ} \mathrm{C}$, which is much higher than with $\mathrm{T}_{\text {dry }}$ values assumed in other studies and slightly less than the energy balance models developed by Jones [111]. $\mathrm{T}_{\mathrm{dry}}$ for calculation of the CWSI was estimated as $\mathrm{T}_{\text {air }}+15^{\circ} \mathrm{C}$ for both grape cultivars, resulting in a CWSI value between 0 and 1 for irrigation scheduling purposes. The CWSI value obtained was a good representation of a measure of plant water stress. 
Möller et al. [108] studied the effect of different irrigation treatments on grapevines for achieving a higher fruit quality when the vineyard was subjected to mild-to-moderate levels of water stress. The authors found a higher accuracy for determining CWSI combining thermal and visible images, and adopting the following assumptions: (i) CWSI calculated with air temperature $+5{ }^{\circ} \mathrm{C}$ and (ii) $\mathrm{T}_{\text {wet }}$ assumed to be the average temperature of the wet artificial reference surface. Other surface temperatures were obtained by wetting the canopy surface before thermal image acquisition and from the energy balance according to Jones [164]. There was a stable linear relationship when $\mathrm{T}_{\text {wet }}$ was derived from the energy balance and from image analysis of a wetted part of the canopy. The authors suggested in-depth study was needed to develop this calculation as a tool for irrigation management on a field scale.

López-López et al. [135] reported that in case of no transpiration, the difference between the $\mathrm{T}_{\text {air }}$ and the $\mathrm{T}_{\text {crop }}$ averaged $2.8^{\circ} \mathrm{C}(\mathrm{n}=25)$. Irmak et al. [201] determined an average value of $4.6^{\circ} \mathrm{C}$ for corn.

Orta et al. [171] determined in a study of trickle-irrigated watermelon upper baseline limits of 3.3 and $3.4{ }^{\circ} \mathrm{C}$. Santesteban et al. [173] preferred the approach suggested by Jones et al. [156], whereby leaves of two sampled grapevines were coated on both sides with petroleum jelly to prevent leaf transpiration and interrupt the transpiration-cooling phenomenon, simulating the leaf physiological response to water stress conditions. The authors report a variation in vineyard temperature range of the $\left(\mathrm{T}_{\text {dry }}\right.$ and $\left.\mathrm{T}_{\text {wet }}\right) \mathrm{h}$ of about $1.3^{\circ} \mathrm{C}$ and $2.4^{\circ} \mathrm{C}$, respectively.

King and Shellie [163] adopted a neural model to estimate daily mean CWSI starting from well-watered leaf temperatures and air temperature plus $15{ }^{\circ} \mathrm{C}$ for a non-transpiring leaf temperature (between 13:00 and 15:00 MDT). They were able to discriminate between deficit irrigation amounts, irrigation events, and rainfall. In contrast, Park et al. [203] estimated the lower boundary temperature, representing the temperature of fully transpiring leaves, while the temperature of a non-transpiring leaf $\left(\mathrm{T}_{\text {dry }}\right)$ was determined by air temperature at $+6{ }^{\circ} \mathrm{C}$.

Zarco-Tejada et al. [145] found $\mathrm{T}_{\mathrm{c}}-\mathrm{T}_{\text {air }}$ of well-irrigated grapes was effectively determined as $\mathrm{T}_{\mathrm{c}}-\mathrm{T}_{\text {air }}=0695-1.575 \times \mathrm{VPD}$.

Mangus et al. [186] derived an instantaneous CWSI using air temperature, relative humidity, and solar radiance. $\mathrm{T}_{\text {wet }}$ reference were empirically found using well-watered plants, while a standardized $\mathrm{T}_{\text {dry }}$ reference of $5{ }^{\circ} \mathrm{C}$ above air temperature was utilized to represent the upper leaf temperature. The same results were obtained by DeJonge et al. [192] with an upper baseline of $5^{\circ} \mathrm{C}$ and a linear relation with VPD.

Grant et al. [204] studied the effect of the canopy architecture on the crop temperatures of two grapevine cultivars grown under two irrigation regimes (fully and not irrigated). They concluded that it was desirable to calculate an average over several leaves per canopy in order to reduce the effect of variation in leaf angles. The simple CWSI, without further data acquisition, was sufficient for detecting the relative stress required for scheduling irrigation.

\section{Time of Measurements}

Testi et al. [175] found that the CWSI measured in the early afternoon hours was a good descriptor of water status of a pistachio orchard. Ghaemi et al. [205] developed baseline equation to calculate eggplant CWSI reflecting water deficit and salinity stresses, and also studied the effect of growth environment (field and greenhouse) on eggplant CWSI values and its relationship with crop evapotranspiration and yield. CWSI values were significantly affected by water deficit and salinity, and rising levels of water salinity decreased the slope of the lower baseline in both crop conditions, along with a rise in the upper baseline.

García-Tejero et al. [183] found that the best time to obtain robust and more physiologically meaningful thermal data to assess grapevine water status was between $11: 00 \mathrm{~h}$ and 14:00 $\mathrm{h}$, independent of the variety. 
Taghvaeian et al. [182] found differences in estimating CWSI at different times of day. The smallest difference was from 10:00 to 11:00 $\mathrm{h}$ and the highest from 12:00 to 13:00 $\mathrm{h}$ periods. In their study, they combined IR thermometry with some weather parameters to develop non-water-stressed and non-transpiring baselines for irrigated maize in of Colorado (USA).

King and Shelliey [163] reported that clouds (thin cirrus), often present during the best two-hour-time for CWSI monitoring, rapidly caused changes in levels of solar radiation and, as a consequence, an effect on $\mathrm{T}_{\mathrm{nws}}$. They also provided a detailed description of physiological variations within a canopy; particular attention was given to rapid changes of leaf temperature in response to environmental fluctuations (e.g., air turbulence, changing radiation). For this reason, they proposed the adoption of a 2-h-averaged CWSI value based on 15-min average measured values (canopy temperature, air temperature, solar radiation, relative humidity, and wind speed), which provided a sound daily CWSI value under variable climatic conditions. The results appeared to be consistent even when comparing two grape cultivars, characterized by different canopy temperature in response to climatic conditions and irrigation conditions.

Bellvert et al. [172] found a good estimate for the calculated daily mean CWSI of well-watered leaves between 10:00 and 16:00 h. Berni et al. [84], using airborne thermal data of an olive orchard, found the best results from 07:30 to 09:30; however, at 12:30 h there was an overestimate of canopy conductance values. Bellvert et al. [202] found that the correlation between CWSI and $\Psi_{\mathrm{L}}$ had different $R^{2}$ values at different hours of measurements ( 0.46 at 09:30 and 0.71 at 12:30), suggesting that the latter was the more favorable time for obtaining thermal images that were linked with $\Psi_{\mathrm{L}}$ values.

In Zarco-Tejada et al. [145], CWSI was measured from 13:00 to 15:30 coinciding with the times at which the non-stressed baseline was obtained.

\subsection{Remote Sensing and Soil}

Soil moisture measurements are critical components for climate studies, hydrology, weather predictions, analysis of flooded areas or the recharge of aquifers. Real time analysis of the soil water content is crucial for optimizing water management of agricultural fields.

Nichols et al. [206] presented an overview of soil-moisture retrieval methods using different remote sensing data (active or passive). They reported the advantages and limitations of each method, and the evaluation of the most robust methods for retrieving soil-moisture information from bare and vegetated soils. The best results come from a combination of active and passive sensing methods. A backscatter empirical model (active method) gave a 95-97\% correlation between the estimated and the field soil measurements. The "neural networks method" (passive method) gave a 100\% correlation between the estimated and field soil measurements.

Roussel et al. [62] reported the adoption of GNSS reflectometry (GNSS-R) based on a low-cost device and an airborne solution. For irrigation purposes, the GNSS-R system was useful for soil moisture monitoring. Classical probes were not considered representative of the field-soil moisture since they return punctual measurements. The authors considered the soil moisture monitored on a large scale to be appropriate, even at the expense of temporal and/or spatial resolution. Even satellite measurements were not sufficient to monitor diurnal variations.

Yueh et al. [207] provided a review of the calibration, validation and assessment of Soil Moisture Active Passive (SMAP) instruments. The project conducted two activities aimed at enhancing the products' resolution: (i) the Backus Gilbert interpolation and de-convolution techniques based on the oversampling characteristics of the SMAP radiometer; (ii) the disaggregation of the SMAP radiometer data using the Sentinel-1 C-band synthetic aperture radar data to obtain a resolution from $1 \mathrm{~km}$ to $3 \mathrm{~km}$.

Mulder et al. [208] studied microwave remote sensing of soil moisture content. The system was founded on the different dielectric properties of water with respect to dry soil. The Soil Water Index (SWI) was combined with the METOP ASCAT and ENVISAT ASAR GM to obtain one layer with high resolution $(1 \mathrm{~km})$. The authors reported another way of assessing soil moisture, the Soil Energy 
BALance (SEBAl). All of these models were applied on a local scale to produce the actual ET linked to soil water. The authors indicated that the most broadly used methods were the SEBAL, the Two-Source Energy Balance (TSEB) modeling approach, and the Surface Energy Balance System (SEBS).

Mangus et al. [186] performed a full-season experiment in a greenhouse with several objectives. Since CWSI (values between 0.6 and 1.0) was negatively correlated to soil moisture, the index may be considered "as an alternate irrigation scheduling method to quantify spatial soil moisture".

Other information is reported in the previous Sections 3.2.1 and 3.2.4.

\subsubsection{Vegetation Indices}

Different indexes have been set up to estimate different crop parameters (e.g., crop density, biomass, chlorophyll, nitrogen, water content, etc.); the Enhanced Vegetation Index (EVI), the Soil Adjusted Vegetation Index (SAVI), the Simple Ratio (SR), and the Normalized Difference Vegetation Index (NDVI), are measures of canopy greenness, which may be related to physiological processes such as transpiration and photosynthesis [209-211].

Zhao et al. [212] studied the relationship between stem water potential (SWP) and VIs extracted from high spatial resolution images. A circle mission was conducted to evaluate the effects of bidirectional reflectance distribution fraction (BRDF) and canopy NDVI mean. The authors demonstrated the importance of BRDF to infer SWP from NDVI mean. Circle missions indicated that view angle influenced the canopy NDVI. This could lead to a prediction error of SWP of up to 12 bars. Further analysis of images identified a non-normalized difference vegetation index (NNDVI) based on ground-derived measurements over three weeks that showed a more significant relationship with SWP than the canopy NDVI mean.

Zúñiga et al. [213], in a study on a remote sensing-based WUE evaluation of sub-surface irrigated grape vines, compared several irrigation methods. Differences in NDVI values occurred among different irrigation strategies (surface and subsurface irrigation methods) and when irrigation rates were compared. Multispectral satellite imagery, particularly with a red edge waveband, demonstrated the potential for quantifying soil-moisture-tension variability, and hence could be used for variable rate irrigation management. Red Edge Normalized Difference Vegetation Index (RENDVI) was especially sensitive to soil moisture tension and demonstrated that a single image could be representative of variability up to two weeks after acquisition. However, it will be necessary to confirm the repeatability of these results at more maize growth stages and with other crops. Finally, an economic study to evaluate the monetary and environmental implications of such management at a field scale would help transition these findings into adoption by growers [214].

Toureiro et al. [215] presented work on the use of remote sensing for measuring soil water availability for optimizing crop growth. Data were determined by satellite and integrated with atmosphere and crop parameters to calculate biophysical indicators and indices of water stress by NDVI, Kc, and Kcb. The results showed that remote sensing based on multispectral images may be used, with a high degree of accuracy and spatial representation, to calculate crop water and irrigation requirements. However, frequent mapping of soil water status and crop irrigation requirements would be required; this is the weakest point of the satellite imagery methodology used. Temporal representation, once each 16 days with the Landsat 5 satellite, would not be enough for irrigation management. The Sentinel 2 satellite is available and could be combined with data from other satellites to provide more frequent images of the land surface.

\subsubsection{WUE}

Marino et al. [216] evaluated the use of soil and vegetation spectroradiometry to investigate crop water use efficiency of drip-irrigated tomato. A new instrument to measure in-depth soil moisture was tested combined with the Hargreaves method and VIs with the goal of reducing irrigation volume, to assess crop spatial variability, and to identify the best VIs related to WUE, at a field scale. The tomato 
crop was drip irrigated by an automated precision system, which maintained the soil water content within a specific range related to growth stage and environmental conditions.

The instrument recorded the soil moisture at different soil depths, providing information on the amount of water to apply, taking into account-at each watering - the volume of the root zone explored by the crop. The results confirmed that the system saved water, applying lower soil water depths than those calculated with the Hargreaves formula. The field was divided into three clusters, characterized by increasing WUE. The highest $(\mathrm{H})$ cluster showed a WUE value of $35.1 \mathrm{~kg} \cdot \mathrm{m}^{-3}$; the lowest (L) showed WUE a value of $23.1 \mathrm{~kg} \cdot \mathrm{m}^{-3}$. Among VIs tested, the Perpendicular vegetation index (PVI), Soil Adjustment Vegetation Index (SAVI), optimized Soil Adjustment Vegetation Index (OSAVI), and Weighted Difference Vegetation (WDVI) were significantly related to tomato crop yield. The authors concluded that "PVI proved to be a useful tool for (i) a better understanding of the different field productive areas and for (ii) the adoption of variable water rate application according to the different PVI values. The irrigation system adopted proved to be effective from agronomic and environmental point of view".

Similar probes were used by Nolz et al. [217] to monitor soil water in a vineyard for irrigation management. Wang et al. [218] studied the application of quick techniques based on thermal imaging and visual-NIR spectroscopy for measuring WUE in millet. The authors suggested that the exact spectral parameters used for measuring physiological factors (e.g., E, $\mathrm{g}_{\mathrm{s}}$, leaf and WUE) may be used for estimating response of crops to changes in the environmental conditions.

\section{Conclusions}

The advances in electronic and information technologies have developed various non-invasive sensing systems, which return accurate georeferred information on spatial variability within fields. The sensing systems utilize sensors and instruments that produce a huge amount of data at different scales (temporal and spatial) and distances from the target. Remote (satellite, airborne and UAV imageries) and proximal sensors (mounted on tractors, poles or towers, and portable specto-radiometers) are able to detect soil and crop information, such as soil status and traits, crop yield, canopy volume and biomass, crop water status, and pests (disease, weeds, and insects). These sensing technologies cane be used for precision agriculture and irrigation management.

Soaring investments in R\&D have spurred all branches of knowledge linked to RS, boosting the production of reliable and accurate sensors. Temporal frequency of RS imagery has also improved consistently, although it has been impaired by considerable lengthening of the average times for data processing. Data processing of images necessitates adequate hardware, specific expertise, skills and funds, which are likely to be provided only by specialized reprocessing companies.

Overall, there are numerous studies with spatially distributed information on ET and plant water status. These approaches use reflectance, including thermal radiance, measurements of the surface, vegetation index-based crop coefficients, surface energy balance models, and soil water balance (although limited to the upper soil layer).

On a small scale, the focus on time and space has significantly improved the monitoring of the crop water status of many crops, especially orchards and vineyards. The estimation of ET and kc, of appearance of biotic and abiotic stresses, of crop spatial variability, and of canopy volume have been improved significantly. On a field scale, the attention paid to soil-water status seems inadequate, although soil moisture monitoring is a prerequisite for professionally controlled irrigation that satisfies crop water requirements (precision irrigation) and reduces inefficient spatial allocation of irrigation water, in particular over irrigation that causes $\mathrm{N}$ leaching. There are current limits of RS, which can answer the question of "when to apply water", because the irrigation volume needs to be estimated based on other methods, as wisely pointed out by Taghvaeian et al. [182] These other methods, include-amongst many - the use of electronic probes measuring crop water consumption [113], with the aim of defining the right water depth to apply to a field, and hopefully to each homogeneous area. 
Since positive correlations between crop-water status and yield vary among crops, RS studies on irrigation should pay more attention to field production, either in absolute terms (maximizing field productivity) or in relative terms (higher WUE).

In the near future, it is likely that all available tools (multi-temporal images combined with models and improved sensors) will contribute to monitoring crop status for triggering irrigation. As mentioned above, doubts persist on their ability to estimate the water delivery to the field for each crop, or to different zones in the case of high crop spatial variability.

A holistic approach is necessary for moving toward precision irrigation. It will be necessary to set up networks that contemplate the participation of public/private partnerships, universities, and research institutes, for producing multi-temporal images, models, sensors and data sets [94] for managing precision irrigation. Among several EU hubs of excellence, the Quantalab IAS - CSIC in Spain focuses on quantitative methods for remote sensing in agriculture and forestry, for a wide application of precision agriculture and precision irrigation, for the assessment of environmental impacts and stress detection.

Other scientists are pursuing grassroots remote sensing and democratic mapping. Anderson et al. [93] have generated a toolkit using drones, live coding, smartphones and kites.

For all institutions developing RS, a key factor will be the operational readiness of information provided to farmers and technicians for managing irrigation. For irrigation purposes, it will be necessary to develop techniques and interpretative frameworks to provide low-cost and affordable tools and real-time information to stakeholders involved in the management and security of agricultural and related sectors.

Author Contributions: Arturo Alvino and Stefano Marino have contributed in equal part to the present review.

Conflicts of Interest: The authors declare no conflict of interest.

\section{References}

1. Scheierling, S.M.; Treguer, D.O.; Booker, J.F.; Decker, E. How to Assess Agricultural Water Productivity? Looking for Water in the Agricultural Productivity and Efficiency Literature; Policy Research Working Paper 6982; Water Global Practice Group and Agriculture Global Practice Group, The World Bank: Washington, DC, USA, 2014.

2. Godfray, H.C.J.; Beddington, J.R.; Crute, I.R.; Haddad, L.; Lawrence, D.; Muir, J.F.; Pretty, J.; Robinson, S.; Thomas, S.M.; Toulmin, C. Food security: The challenge of feeding 9 billion people. Science 2010, 327, 812-818. [CrossRef] [PubMed]

3. Ray, D.K.; Mueller, N.D.; West, P.C.; Foley, J.A. Yield Trends Are Insufficient to Double Global Crop Production by 2050. PLoS ONE 2013, 8, e66428. [CrossRef] [PubMed]

4. Alexandratos, N.; Bruinsma, J. World Agriculture Towards 2030/2050; The 2012 Revision, ESA Working Paper No. 12-03; Food and Agriculture Organization of the United Nations: Rome, Italy, 2012.

5. Tilman, D.; Balzer, C.; Hill, J.; Befort, B.L. Global food demand and the sustainable intensification of agriculture. Proc. Natl. Acad. Sci. USA 2011, 108, 20260-20264. [CrossRef] [PubMed]

6. Johansson, R.C. Micro and Macro-Level Approach for Assessing the Value of Irrigation Water; World Bank Policy Research Working Paper 3778; World Bank: Washington, DC, USA, 2005.

7. Geoghegan-Quinn, M. Role of Research \& Innovation in Agriculture. European CommissionSPEECH/13/505. Available online: http://europa.eu/rapid/press-releaseSPEECH-13--505\%20en.htm (accessed on 4 June 2013).

8. Fereres, E. The Future of Irrigation in Horticulture. Chron. Horticult. 2008, 48, 9-11.

9. Singh, A.K.; Dubey, O.P.; Ghosh, S.K. Irrigation scheduling using intervention of Geomatics tools. A case study of Khedli minor. Agric. Water Manag. 2016, 177, 454-460. [CrossRef]

10. Dudu, H.; Chumi, S. Economics of Irrigation Water Management: A Literature Survey with Focus on Partial and General Equilibrium Models; Policy Research Working Paper 4556; The World Bank Development Research Group, Sustainable Rural and Urban Development Team: Washington, DC, USA, 2008.

11. Rosegrant, M.W.; Ringler, C.; Zhu, T. Water for agriculture: Maintaining food security under growing scarcity. Annu. Rev. Environ. Resour. 2009, 34, 205-222. [CrossRef] 
12. Pereira, L.S.; Oweis, T.; Zairi, A. Irrigation management under water scarcity. Agric. Water Manag. 2002, 57, 175-206. [CrossRef]

13. Molden, D.; Oweis, T.; Steduto, P.; Bindraban, P.; Hanjra, M.A.; Kijne, J. Improving agricultural water productivity: Between optimism and caution. Agric. Water Manag. 2010, 97, 528-535. [CrossRef]

14. Parry, M.; Rosenzweig, C.; Livermore, M. Climate change, global food supply and risk of hunger. Philos. Trans. R. Soc. B 2005, 360, 2125-2138. [CrossRef] [PubMed]

15. Painter, D.; Carren, P. What is irrigation efficiency? Soil Water 1978, 14, 15-22.

16. Batchelor, C. Improving water use efficiency as part of integrated catchment management. Agric. Water Manag. 1999, 40, 249-263. [CrossRef]

17. Wallace, J.S.; Batchelor, C.H. Managing water resources for crop production. Philos. Trans. R. Soc. Lond. B 1997, 352, 937-947. [CrossRef]

18. Costa, J.M.; Ortuño, M.F.; Chaves, M.M. Deficit Irrigation as a Strategy to Save Water: Physiology and Potential Application to Horticulture. J. Integr. Plant Biol. 2007, 49, 1421-1434. [CrossRef]

19. Marino, S.; Cocozza, C.; Tognetti, R.; Alvino, A. Use of proximal sensing and vegetation indexes to detect the inefficient spatial allocation of drip irrigation in a spot area of tomato field crop. Precis. Agric. 2015, 16, 613-629. [CrossRef]

20. Jones, H.G. Irrigation scheduling advantages and pitfalls of plant-based methods. J. Exp. Bot. 2004, 55, 2427-2436. [CrossRef] [PubMed]

21. Kirnak, H.; Demirtas, M.N. Effects of Different Irrigation Regimes and Mulches on Yield and Macronutrition Levels of Drip-Irrigated Cucumber under Open Field Conditions. J. Plant Nutr. 2006, 9, 1675-1690. [CrossRef]

22. Çetin, O.; Uyganb, D. The effect of drip line spacing, irrigation regimes and planting geometries of tomato on yield, irrigation water use efficiency and net return. Agric. Water Manag. 2008, 95, 949-958. [CrossRef]

23. Ismail, S.M.; Ozawa, K.; Khondaker, N.A. Influence of single and multiple water application timings on yield and water use efficiency in tomato (var. First power). Agric. Water Manag. 2008, 95, 116-122. [CrossRef]

24. Wright, J. Irrigation Scheduling Checkbook Method. Communication and Educational Technology Services; University of Minnesota: Minneapolis, MN, USA, 2002.

25. Hoffman, G.J.; Martin, D.L. Engineering systems to enhance irrigation performance. Irrig. Sci. 1993, 14, 53-63. [CrossRef]

26. Raine, S.R.; Meyer, W.S.; Rassam, D.W.; Hutson, J.L.; Cook, F.J. Soil-water and solute movement under precision irrigation: Knowledge gaps for managing sustainable root zones. Irrig. Sci. 2007, 26, 91-100. [CrossRef]

27. Köksal, E.S.; Kara, T.; Apan, M.; Üstün, H.; Ilbeyi, A. Estimation of green bean yield, water deficiency and productivity using spectral indexes during the growing season. Irrig. Drain. Syst. 2008, 22, 209-223. [CrossRef]

28. Moran, M.S.; Inoue, S.; Barnes, E.M. Opportunities and limitations for image-based remote sensing in precision crop management. Remote Sens. Environ. 1997, 61, 319-346. [CrossRef]

29. Monaghan, J.M.; Daccache, A.; Vickers, L.H.; Hes, T.M.; Weatherhead, E.K.; Grove, I.G.; Knox, J.W. More 'crop per drop' —constraints and opportunities for precision irrigation in European agriculture. J. Sci. Food Agric. 2013, 93, 977-980. [CrossRef] [PubMed]

30. Fernández, J.E. Plant-based sensing to monitor water stress: Applicability to commercial orchards. Agric. Water Manag. 2014, 142, 99-109. [CrossRef]

31. Jensen, T.; Apan, A.; Young, F.; Zeller, L. Detecting the attributes of a wheat crop using digital imagery acquired from a low-altitude platform. Comp. Electron. Agric. 2007, 59, 66-77. [CrossRef]

32. Panda, S.S.; Rao, M.N.; Thenkabail, P.S.; Fitzerald, J.E. Remote Sensing Systems_Platforms and Sensors: Aerial, Satellite, UAV, Optical, Radar, and LiDAR; CRC Press: Boca, Raton, FL, USA, 2016.

33. Lillesand, T.; Kiefer, R.W.; Jonathan Chipman, J. Remote Sensing and Image Interpretation, 7th ed.; John Wiley \& Sons: Hoboken, NJ, USA, 2015.

34. Toth, C.; Jóźków, G. Remote sensing platforms and sensors: A survey. J. Photogramm. Remote Sens. 2016, 115, 22-36. [CrossRef]

35. Mather, P.; Tso, B. Classification Methods for Remotely Sensed Data, 2nd ed.; Brand, T., Paul, M., Eds.; CRC Press: Boca, Raton, FL, USA, 2016; p. 379.

36. Konecny, G. Geoinformation: Remote Sensing, Photogrammetry and Geographic Information Systems, 2nd ed.; CRC Press: Boca, Raton, FL, USA, 2014; p. 472. 
37. Shaw, G.A.; Burke, H.-H.K. Spectral Imaging for Remote Sensing. Linc. Lab. J. 2003, 1, 3-28.

38. Shia, C.; Wanga, L. Incorporating spatial information in spectral unmixing: A review. Remote Sens. Environ. 2014, 149, 70-87. [CrossRef]

39. Jawak, S.D.; Devliyal, P.; Luis, A.J. A Comprehensive Review on Pixel Oriented and Object Oriented Methods for Information Extraction from Remotely Sensed Satellite Images with a Special Emphasis on Cryospheric Applications. Adv. Remote Sens. 2015, 4, 177-195. [CrossRef]

40. Jones, H.G.; Vaughan, R.A. Remote Sensing of Vegetation, Principles, Techniques, and Applications; Oxford Press University: Oxford, UK, 2011; p. 384.

41. Gibson, P.; Power, C. Introductory Remote Sensing Principles and Concepts; Taylor, Francis, Ed.; Routledge: London, UK, 2013; p. 216.

42. Lucas, R.; Rowlands, A.; Brown, A.; Keyworth, S.; Bunting, P. Rule-based classification of multi-temporal satellite imagery for habitat and agricultural land cover mapping. ISPRS J. Photogramm. Remote Sens. 2007, 62, 165-185. [CrossRef]

43. Langley, S.K.; Cheshire, H.M.; Humes, K.S.A. Comparison of single date and multitemporal satellite image classifications in a semi-arid grassland. J. Arid Environ. 2001, 49, 401-411. [CrossRef]

44. Sexton, J.O.; Urban, D.L.; Donohue, M.J.; Song, C. Long-term land cover dynamics by multi-temporal classification across the Landsat-5 record. Remote Sens. Environ. 2013, 128, 246-258. [CrossRef]

45. Guerschman, J.P.; Paruelo, J.M.; Di Bella, C.; Giallorenzi, M.C.; Pacin, F. Land cover classification in the Argentine Pampas using multi-temporal Landsat TM data. Int. J. Remote Sens. 2010, 24, 3381-3402. [CrossRef]

46. Schowengerdt, R.A. Remote Sensing: Models and Methods for Image; Academic Press: Cambridge, MA, USA, 2006; p. 560.

47. Campbell, J.B.; Wynne, R.H. Introduction to Remote Sensing, 5th ed.; The Guilford Press: New York, NY, USA, 2011; p. 667.

48. Lee, W.S.; Alchanatis, V.; Yang, C.; Hirafuji, M.; Moshou, D.; Li, C. Sensing technologies for precision specialty crop production. Comput. Electron. Agric. 2010, 74, 2-33. [CrossRef]

49. Ruiz-Altisent, M.; Ruiz-Garcia, L.; Moreda, G.P.; Renfu, L.; Hernandez-Sanchez, N.; Correa, E.C.; Diezma, B.; Nicola, B.; Garca-Ramos, J. Sensors for product characterization and quality of specialty crops a review. Comput. Electron. Agric. 2010, 74, 176-194. [CrossRef]

50. Wang, N.; Zhang, N.; Wang, M. Wireless sensors in agriculture and food industry-Recent development and future perspective. Comput. Electron. Agric. 2006, 50, 1-14. [CrossRef]

51. Matese, A.; Toscano, P.; Di Gennaro, S.F.; Genesio, L.; Vaccari, F.P.; Primicerio, J.; Belli, C.; Zaldei, A.; Bianconi, R.; Gioli, B. Intercomparison of UAV, Aircraft and Satellite Remote Sensing Platforms for Precision Viticulture. Remote Sens. 2015, 7, 2971-2990. [CrossRef]

52. Tyc, G.; Tulip, J.; Schulten, D.; Krischke, M.; Oxfort, M. The RapidEye mission design. Acta Astronaut. 2005, 56, 213-219. [CrossRef]

53. Anderson, K. Integrating multiple scales of remote sensing measurement-From satellites to kites progress. Phys. Geogr. 2016, 40, 187-195. [CrossRef]

54. Dunn, C.; Bertiger, W.; Bar-Sever, Y.; Desai, S.; Haines, B.; Kuang, D.; Franklin, G.; Harris, I.; Kruizinga, G.; Meehan, T.; et al. Application challenge-instrument of grace-GPS augments gravity measurements. GPS World 2003, 14, 16-29.

55. Poli, D.; Toutin, T. Review of developments in geometric modelling for high resolution satellite push broom sensors. Photogram. Rec. 2012, 27, 58-73. [CrossRef]

56. Yang, C.; Everitt, J.H.; Bradford, J.M. Comparison of QuickBird satellite imagery and airborne imagery for mapping grain sorghum yield patterns. Precis. Agric. 2006, 7, 33-44. [CrossRef]

57. Yang, C.; Everitt, J.H.; Bradford, J.M. Evaluating high resolution SPOT 5 satellite imagery to estimate crop yield. Precis. Agric. 2009, 10, 292-303. [CrossRef]

58. Dekker, A.G.; Vos, R.J.; Peters, S.W.M. Comparison of remote sensing data, model results and in situ data for total suspended matter (TSM) in the southern Frisian lakes. Sci. Total Environ. 2001, 268, 197-214. [CrossRef]

59. Olmanson, L.G.; Bauer, M.E.; Brezonik, P.L. A 20-year Landsat water clarity census of Minnesota's 10,000 lakes. Remote Sens. Environ. 2008, 112, 4086-4097. [CrossRef]

60. Kallio, K.; Attila, J.; Härmä, P.; Koponen, S.; Pulliainen, J.; Hyytiäinen, U.M.; Pyhälahti, T. Landsat ETM+ images in the estimation of seasonal lake water quality in boreal river basins. Environ. Manag. 2008, 42, 511-522. [CrossRef] [PubMed] 
61. Kutser, T. The possibility of using the Landsat image archive for monitoring long time trends in coloured dissolved organic matter concentration in lake waters. Remote Sens. Environ. 2012, 123, 334-338. [CrossRef]

62. Roussel, N.; Darrozes, J.; Ha, C.; Boniface, K.; Frappart, F.; Ramillien, G.; Gavart, M.; Van de Vyvere, L.; Desenfans, O.; Baup, F. Multi-scale volumetric soil moisture detection from GNSS SNR data: Ground-based and airborne applications. In Proceedings of the 2016 IEEE Metrology for Aerospace (MetroAeroSpace), Florence, Italy, 22-23 June 2016.

63. Van der Werff, H.; van der Meer, F. Sentinel-2 for Mapping Iron Absorption Feature Parameters. Remote Sens. 2015, 7, 12635-12653. [CrossRef]

64. Toming, K.; Kutser, T.; Laas, A.; Sepp, M.; Paavel, B.; Nõges, T. First Experiences in Mapping Lake Water Quality Parameters with Sentinel-2 MSI Imagery. Remote Sens. 2016, 8, 640. [CrossRef]

65. Immitzer, M.; Vuolo, F.; Atzberger, C. First Experience with Sentinel-2 Data for Crop and Tree Species Classifications in Central Europe. Remote Sens. 2016, 8, 166. [CrossRef]

66. Saadi, S.; Simonneaux, V.; Boulet, G.; Raimbault, B.; Mougenot, B.; Fanise, B.; Ayari, H.; Lili-Chabaane, Z. Monitoring Irrigation Consumption Using High Resolution NDVI Image Time Series: Calibration and Validation in the Kairouan Plain (Tunisia). Remote Sens. 2015, 7, 13005-13028. [CrossRef]

67. Escorihuela, M.J.; Quintana-Seguí, P. Comparison of remote sensing and simulated soil moisture datasets in Mediterranean landscapes. Remote Sens. Environ. 2016, 180, 99-114. [CrossRef]

68. Entekhabi, D.; Yueh, S.; Neill, P.O.; Kellogg, K. SMAP Handbook; JPL Publication JPL 400-1567; Jet Propulsion Laboratory: Pasadena, CA, USA, 2014; p. 182.

69. Microwave Technologies Review and Strategy; Valinia, A.; Kunkee, D.; Mayo, D., Eds.; NASA Earth Science Technology Office (ESTO): Washington, DC, USA, 2016.

70. Piles, M.; Entekhabi, D.; Konings, A.G.; McColl, K.A.; Das, N.N.; Jagdhuber, T. Multi-temporal microwave retrievals of Soil Moisture and vegetation parameters from SMAP. In Proceedings of the 2016 IEEE International Geoscience and Remote Sensing Symposium (IGARSS), Beijing, China, 10-15 July 2016.

71. Kojima, Y.; Oki, K.; Noborio, K.; Mizoguchi, M. Estimating soil moisture distributions across small farm fields with ALOS/PALSAR. Int. Sch. Res. Not. 2016, 8, 4203783. [CrossRef] [PubMed]

72. Ye, X.; Sakai, K.; Manago, M. Prediction of citrus yield from airborne hyperspectral imagery. Precis. Agric. 2007, 8, 111. [CrossRef]

73. Goel, P.K.; Prasher, S.O.; Patel, R.M.; Smith, D.L.; DiTommaso, A. Use of airborne multi-spectral imagery for weed detection in field crops. Trans. ASAE 2002, 45, 443-449.

74. Goel, P.K.; Prasher, S.O.; Landry, J.A.; Patel, R.M.; Viau, A.; Miller, J.R. Estimation of crop biophysical parameters through airborne and field hyperspectral remote sensing. Trans. ASAE 2003, 46, 1235-1246.

75. Milton, E.J. Review article principles of field spectroscopy. Int. J. Remote Sens. 1987, 8, 1807-1827. [CrossRef]

76. Godwin, R.J.; Miller, P.C.H. A review of the technologies for mapping within-field variability. Biosyst. Eng. 2003, 84, 393-407. [CrossRef]

77. Rosenqvist, A.; Milne, A.; Lucas, R.; Imhoff, M.; Dobson, C. A review of remote sensing technology in support of the Kyoto protocol. Environ. Sci. Policy 2003, 6, 441-455. [CrossRef]

78. Zarco-Tejada, P.J.; Ustin, S.L.; Whiting, M.L. Temporal and spatial relationships between within-field yield variability in cotton and high-spatial hyperspectral remote sensing imagery. Agric. J. 2005, 97, 641-653. [CrossRef]

79. Yang, C.; Everitt, J.H.; Bradford, J.M. Airborne hyperspectral imagery and yield monitor data for estimating grain sorghum yield variability. Trans. ASAE 2004, 47, 915-924. [CrossRef]

80. Cho, M.A.; Skidmore, A.; Corsi, F.; van Wieren, S.E.; Sobhan, I. Estimation of green grass/herb biomass from airborne hyperspectral imagery using spectral indices and partial least squares regression. Int. J. Appl. Earth Obs. Geoinf. 2007, 9, 375-391. [CrossRef]

81. Huang, W.; Lamb, D.W.; Niu, Z.; Zhang, Y.; Liu, L.; Wang, J. Identification of yellow rust in wheat using in-situ spectral reflectance measurements and airborne hyperspectral imaging. Precis. Agric. 2007, 8, 187-197. [CrossRef]

82. Alvino, A.; Zerbi, G. Water-table level effect on the yield of irrigated and unirrigated grain maize. Trans. ASAE 1986, 29, 1086-1089. [CrossRef]

83. Alvino, A.; Boccia, F.; Amato, M. Root dynamics of peach as a function of winter water table level and rootstock. Sci. Hortic. 1994, 56, 275-290. [CrossRef] 
84. Berni, J.A.J.; Zarco-Tejada, P.J.; Suárez, L.; González-Dugo, V.; Fereres, E. Remote sensing of vegetation from UAV platforms using lightweight multispectral and thermal imaging sensors. Int. Arch. Photogramm. Remote Sens. Spat. Inf. Sci. 2009, 38, 6.

85. Zhang, C.; Kovacs, J.M. The application of small-unmanned aerial systems for precision agriculture: A review. Precis. Agric. 2012, 13, 693. [CrossRef]

86. Nebiker, S.; Annena, A.; Scherrerb, M.; Oeschc, D. A light-weight multispectral sensor for micro $\mathrm{UAV}-$ Opportunities for very high resolution airborne remote sensing. Int. Arch. Photogramm. Remote Sens. Spat. Inform. Sci. 2008, 37, 1193-1198.

87. Watts, A.C.; Ambrosia, V.G.; Hinkley, E.A. Unmanned aircraft systems in remote sensing and scientific research: Classification and considerations of use. Remote Sens. 2012, 4, 1671-1692. [CrossRef]

88. DeBell, L.; Anderson, K.; Brazier, R.E.; King, N.; Jones, L. Water resource management at catchment scales using lightweight UAVs: Current capabilities and future perspectives. J. Unmanned Veh. Syst. 2016, 4, 7-30. [CrossRef]

89. Candiago, S.; Remondino, F.; De Giglio, M.; Dubbini, M.; Gattelli, M. Evaluating Multispectral Images and Vegetation Indices for Precision Farming Applications from UAV Images. Remote Sens. 2015, 7, 4026-4047. [CrossRef]

90. Pajeres, G. Overview and current status of remote sensing applications based on unmanned aerial vehicles. Photogramm. Eng. Remote Sens. 2015, 81, 281-329. [CrossRef]

91. Colomina, I.; Molina, P. Unmanned aerial systems for photogrammetry and remote sensing: A review. ISPRS J. Photogramm. Remote Sens. 2014, 92, 79-97. [CrossRef]

92. Sankaran, S.; Khot, L.R.; Zú̃Espinoza, C.; Sanaz Jarolmasjed, C.; Sathuvalli, V.R.; Vandemark, G.J.; Miklas, P.N.; Carter, A.H.; Pumphrey, M.O.; Knowles, N.R.; et al. Low-altitude, high-resolution aerial imaging systems for row and field crop phenotyping: A review. Eur. J. Agron. 2015, 70, 112-123. [CrossRef]

93. Anderson, K.; Griffiths, D.; DeBell, L.; Hancock, S.; Duffy, J.P.; Shutler, J.D. A Grassroots Remote Sensing Toolkit Using Live Coding, Smartphones, Kites and Lightweight Drones. PLoS ONE 2016, 11, 1-22. [CrossRef] [PubMed]

94. Mulla, D.J. Twenty five years of remote sensing in precision agriculture: key advances and remaining knowledge gaps. Biosyst. Eng. 2013, 114, 358-371. [CrossRef]

95. O'Shaughnessy, S.A.; Evett, S.R.; Andrade, A.; Workneh, F.; Price, J.A.; Rush, C.M. Site-specific variable-rate Irrigation as a means to enhance Water Use Efficiency. Trans. ASABE 2016, 59, 239-249.

96. Aqeel-ur-Rehman, Z.A.; Abbasi, A.Z.; Islam, N.; Shaikh, Z.A. A review of wireless sensors and networks' applications in agriculture. Comput. Stan. Interfaces 2014, 36, 263-270. [CrossRef]

97. Damas, M.; Prados, A.M.; Gómez, F.; Olivares, G. HidroBus system: Fieldbus for integrated management of extensive areas of irrigated land. Microprocess. Microsyst. 2001, 25, 177-184. [CrossRef]

98. Evans, R.; Bergman, J. Relationships Between Cropping Sequences and Irrigation Frequency under Self-Propelled Irrigation Systems in the Northern Great Plains (NGP); USDA Annual Report; USDA: Washington, DC, USA, 2003.

99. Morais, R.; Valente, A.; Serôdio, C. A wireless sensor network for smart irrigation and environmental monitoring. In Proceedings of the EFITA/WCCA Joint Congress on IT in Agriculture, Vila Real, Portugal, 25-28 July 2005; pp. 845-850.

100. Basu, T.; Thool, V.; Thool, R.C.; Birajdar, A.C. Computer based Drip Irrigation Control System with Remote Data Acquisition System. In Proceedings of the 4th World Congress of Computers in Agriculture and Natural Resources, Orlando, FL, USA, 24-26 July 2006.

101. Kim, Y.; Evans, R.G.; Iversen, W.M. Remote sensing and control of an irrigation system using a distributed wireless sensor network. IEEE Trans. Instrum. Meas. 2008, 57, 1379-1387.

102. Kim, Y.; Evans, R.G. Software design for wireless sensor-based site-specific irrigation. Comput. Electron. Agric. 2009, 66, 159-165. [CrossRef]

103. Evans, R.G.; LaRue, J.; Stone, K.C.; King, B.A. Adoption of site-specific variable rate sprinkler irrigation systems. Irrig. Sci. 2013, 31, 871-887. [CrossRef]

104. Thompson, R.B.; Gallardo, M.; Valdez, L.C.; Fernández, M.D. Using plant water status to define threshold values for irrigation management of vegetable crops using soil moisture sensors. Agric. Water Manag. 2007, 88, 147-158. [CrossRef] 
105. Fernández, J.E.; Cuevas, M.V. Irrigation scheduling from stem diameter variations: A review. Agric. For. Meteorol. 2010, 150, 135-151. [CrossRef]

106. Thorp, K.R.; Gore, M.A.; Andrade-Sanchez, P.; Carmo-Silva, A.E.; Welch, S.M.; White, J.W.; French, A.N. Proximal hyperspectral sensing and data analysis approaches for field-based plant phenomics. Comput. Electron. Agric. 2015, 118, 225-236. [CrossRef]

107. Peña-Arancibia, J.L.; Mainuddin, M.; Kirby, J.M.; Chiew, F.H.S.; McVicar, T.R.; Vaze, J. Assessing irrigated agriculture's surface water and groundwater consumption by combining satellite remote sensing and hydrologic modelling. Sci. Total Environ. 2016, 542, 372-382. [CrossRef] [PubMed]

108. Möller, M.; Alchanatis, V.; Cohen, Y.; Meron, M.; Tsipris, J.; Naor, A.; Ostrovsky, V.; Sprintsin, M.; Cohen, S. Use of thermal and visible imagery for estimating crop water status of irrigated grapevine. J. Exp. Bot. 2007, 58, 827-838. [CrossRef] [PubMed]

109. Alchanatis, V.; Cohen, Y.; Cohen, S.; Moller, M.; Sprinstin, M.; Meron, M. Evaluation of different approaches for estimating and mapping crop water status in cotton with thermal imaging. Precis. Agric. 2010, 11, $27-41$. [CrossRef]

110. Cohen, Y.; Alchanatis, V.; Meron, M.; Saranga, Y.; Tsipris, J. Estimation of leaf water potential by thermal imagery and spatial analysis. J. Exp. Bot. 2005, 56, 1843-1852. [CrossRef] [PubMed]

111. Jones, H.G. Plants and Microclimate, 2nd ed.; Cambridge University Press: Cambridge, UK, 1992; p. 428.

112. Hsiao, T.C. Plant atmosphere interaction, evapotranspiration and irrigation scheduling. Symposium on Scheduling of irrigation for vegetable crops under field condition. Acta Hortic. 1990, 278, 55-66. [CrossRef]

113. Marino, S.; Alvino, A. Hyperspectral vegetation indices for predicting onion (Allium cepa L.) yield spatial variability. Comput. Electron. Agric. 2015, 16, 109-117. [CrossRef]

114. Casa, R.; Rossi, M.; Sappa, G.; Trotta, A. Assessing Crop Water Demand by Remote Sensing and GIS for the Pontina Plain, Central Italy. Water Resour. Manag. 2009, 23, 1685-1712. [CrossRef]

115. Evett, S. Irrigation Management. In Encyclopedia of Remote Sensing; Njoku, E.G., Ed.; Springer: Berlin/Heidelberg, Germany, 2012; pp. 22-34.

116. Ha, W.; Gowda, P.H.; Howell, T.A. A review of downscaling methods for remote sensing-based irrigation management: Part I. Irrig. Sci. 2013, 31, 831. [CrossRef]

117. Zhang, K.; Kimball, J.S.; Running, S.W. A review of remote sensing based actual evapotranspiration estimation. WIREs Water 2016, 3, 834-853. [CrossRef]

118. Liou, Y.-A.; Kar, S.K. Evapotranspiration Estimation with Remote Sensing and Various Surface Energy Balance Algorithms-A Review. Energies 2014, 7, 2821-2849. [CrossRef]

119. Courault, D.; Sequin, B.; Olioso, A. Review on estimation of evapotranspiration from remote sensing data: From empirical to numerical modeling approaches. Irrig. Drain. Syst. 2005, 19, 223-249. [CrossRef]

120. Santos, C.; Lorite, I.J.; Tasumi, M.; Allen, R.G.; Fereres, E. Integrating satellite-based evapotranspiration with simulation models for irrigation management at the scheme level. Irrig. Sci. 2008, 26, 277-288. [CrossRef]

121. Bastiaanssen, W.G.M.; Menenti, M.; Feddes, R.A.; Holtslag, A.A.M. A remote sensing surface energy balance algorithm for land (SEBAL): 1 Formulation. J. Hydrol. 1998, 212, 213-229. [CrossRef]

122. Allen, R.G.; Tasumi, M.; Trezza, R. Satellite-based energy balance for mapping evapotranspiration with internalized calibration (METRIC)—Model. ASCE J. Irrig. Drain. Eng. 2007, 33, 380-394. [CrossRef]

123. Zhang, H.; Anderson, R.G.; Wang, D. Satellite-based crop coefficient and regional water use estimates for Hawaiian sugarcane. Field Crops Res. 2015, 180, 143-154. [CrossRef]

124. Allen, R.G.; Tasurmi, M.; Morse, A.T.; Trezza, R.A. Landsat-based Energy Balance and Evapotranspiration Model in Western US Water Rights Regulation and Planning. J. Irrig. Drain. Syst. 2005, 19, 251-268. [CrossRef]

125. Senay, G.B.; Budde, M.; Verdin, J.P.; Melesse, A.M. A coupled remote sensing and simplified Surface Energy Balance approach to estimate Actual Evapotranspiration from irrigated fields. Sensors 2007, 7, 979-1000. [CrossRef]

126. Biggs, T.W.; Marshall, M.; Messina, A. Mapping daily and seasonal evapotranspiration from irrigated crops using global climate grids and satellite imagery: Automation and methods comparison. Water Resour. Res. 2016, 52, 7311-7326. [CrossRef]

127. Allen, R.G.; Irmak, A.; Trezza, R.; Hendrickx, J.M.H.; Bastiaanssen, W.; Kjaersgaard, J. Satellite-based ET estimation in agriculture using SEBAL and METRIC. Hydrol. Process. 2011, 25, 4011-4027. [CrossRef] 
128. Lorite, I.J.; Mateos, L.; Fereres, E. Evaluating irrigation performance in a Mediterranean environment. I. Model and general assessment of an irrigation scheme. Irrig. Sci. 2004, 23, 77-84. [CrossRef]

129. Trezza, R.; Allen, R.G.; Tasumi, M. Estimation of Actual Evapotranspiration along the Middle Rio Grande of New Mexico Using MODIS and Landsat Imagery with the METRIC Model. Remote Sens. 2013, 5, 5397-5423. [CrossRef]

130. Elhaddad, A.; Garcia, L. ReSET-Raster: Surface Energy Balance Model for Calculating Evapotranspiration Using a Raster Approach. J. Irrig. Drain. Eng. 2011, 137, 203-210. [CrossRef]

131. Elhaddad, A.; Garcia, L. Using a Surface Energy Balance Model (ReSET-Raster) to Estimate Seasonal Crop Water Use for Large Agricultural Areas: Case Study of the Palo Verde Irrigation District. J. Irrig. Drain. Eng. 2014, 140, 716. [CrossRef]

132. Ortega-Farías, S.; Ortega-Salazar, S.; Poblete, T.; Kilic, A.; Allen, R.; Poblete-Echeverría, C. Estimation of energy balance components over a drip-irrigated olive orchard using thermal and multispectral cameras placed on a helicopter-based unmanned aerial vehicle (UAV). Remote Sens. 2016, 8, 638. [CrossRef]

133. D’Urso, G.; Richter, K.; Calera, A.; Osann, M.A.; Escadafal, R.; Garatuza-Pajan, J.; Hanich, L.; Perdigão, A.; Tapia, B.; Vuolo, F. Earth Observation products for operational irrigation management in the context of the PLEIADeS project. Agric. Water Manag. 2010, 98, 271-282. [CrossRef]

134. Vanino, S.; Pulighe, G.; Nino, P.; De Michele, C.; Falanga Bolognesi, S.; D’Urso, G. Estimation of Evapotranspiration and Crop Coefficients of Tendone Vineyards Using Multi-Sensor Remote Sensing Data in a Mediterranean Environment. Remote Sens. 2015, 7, 14708-14730. [CrossRef]

135. López-López, R.; Ramón, A.R.; Sánchez-Cohen, I.; Bustamante, W.O.; González-Lauck, V. Evapotranspiration and Crop Water Stress Index in Mexican Husk Tomatoes (Physalis ixocarpa Brot). In Evapotranspiration-From Measurements to Agricultural and Environmental Applications; Chapter: 10; Giacomo, G., Ed.; In Tech: Rijeka, Croatia, 2011; pp. 187-210.

136. Kamble, B.; Kilic, A.; Hubbard, K. Estimating Crop Coefficients Using Remote Sensing-Based Vegetation Index. Remote Sens. 2013, 5, 1588-1602. [CrossRef]

137. Battista, P.; Chiesi, M.; Rapi, B.; Romani, M.; Cantini, C.; Giovannelli, A.; Cocozza, C.; Tognetti, R.; Maselli, F. Integration of ground and multi-resolution satellite data for predicting the water balance of a Mediterranean two-layer agro-ecosystem. Remote Sens. 2016, 8, 731. [CrossRef]

138. Marshall, M.; Thenkabail, P.S.; Biggs, T.; Post, K. Hyperspectral narrowband and multispectral broadband indices for remote sensing of crop evapotranspiration and its components (transpiration and soil evaporation). Agric. For. Meteorol. 2016, 218-219, 122-134. [CrossRef]

139. González-Dugo, M.P.; Mateos, L. Spectral vegetation indices for benchmarking water productivity of irrigated cotton and sugarbeet crops. Agric. Water Manag. 2008, 95, 48-58. [CrossRef]

140. Hunsaker, D.J.; Pinter, P.R.; Kimball, B.A. Wheat basal crop coefficients determined by normalized difference vegetation index. Irrig. Sci. 2005, 24, 1-14. [CrossRef]

141. Hunsaker, D.J.; Barnes, E.M.; Clarke, T.R.; Fitzgerald, G.J.; Pinter, P.J., Jr. Cotton irrigation scheduling using remotely sensed and FAO-56 basal crop coefficients. Trans. ASAE 2005, 48, 1395-1407. [CrossRef]

142. Er-Raki, S.; Chehbouni, A.; Guemouria, N.; Duchemin, B.; Ezzahar, J.; Hadria, R. Combining FAO-56 model and ground-based remote sensing to estimate water consumptions of wheat crops in a semi-arid region. Agric. Water Manag. 2007, 87, 41-54. [CrossRef]

143. Choudhury, B.J.; Ahmed, N.U.; Idso, S.B.; Reginato, R.J.; Daughtry, C.S.T. Relations between evaporation coefficients and vegetation indices studied by model simulations. Remote Sens. Environ. 1994, 50, 1-17. [CrossRef]

144. Romero-Triguerosa, C.; Nortes, P.A.; Alarcón, J.J.; Hunink, J.E.; Parra, M.; Contreras, S.; Droogers, P.; Nicolás, E. Effects of saline reclaimed waters and deficit irrigation on Citrus physiology assessed by UAV remote sensing. Agric. Water Manag. 2016, 183, 60-69. [CrossRef]

145. Zarco-Tejada, P.J.; González-Dugo, V.; Williams, L.E.; Suárez, L.; Berni, J.A.J.; Goldhamer, D.; Fereres, E. A PRI-based water stress index combining structural and chlorophyll effects: Assessment using diurnal narrow-band airborne imagery and the CWSI thermal index. Remote Sens. Environ. 2013, 138, 38-50. [CrossRef]

146. Kang, Y.; Özdoğan, M.; Zipper, S.C.; Román, M.O.; Walker, J.; Hong, S.Y.; Marshall, M.; Magliulo, V.; Moreno, J.; Alonso, L. How Universal Is the Relationship between Remotely Sensed Vegetation Indices and Crop Leaf Area Index? Glob. Assess. Remote Sens. 2016, 8, 597. [CrossRef] 
147. Wójtowicz, M.; Wójtowicz, A.; Piekarczyk, J. Application of remote sensing methods in agriculture. Commun. Biometry Crop Sci. 2016, 11, 31-50.

148. Jackson, R.D.; Idso, S.B.; Reginato, R.J.; Pinter, P.J. Canopy temperature as a crop water stress indicator. Water Resour. Res. 1981, 17, 1133-1138. [CrossRef]

149. Jackson, R.D. Remote sensing of biotic and a biotic plant stress. Ann. Rev. Phytopathol. 1986, 24, $265-286$. [CrossRef]

150. Moran, M.S.; Clarke, T.R.; Inoue, Y.; Vidal, A. Estimating crop water deficit using the relation between surface-air temperature and spectral vegetation index. Remote Sens. Environ. 1994, 49, 246-263. [CrossRef]

151. Vidal, A.; Pinglo, F.; Durand, H.; Devaux-Ros, C.; Maillet, A. Evaluation of a temporal fire risk index in mediterranean forests from NOAA thermal IR. Remote Sens. Environ. 1994, 49, 296-303. [CrossRef]

152. Guilioni, L.; Jones, H.G.; Leinonen, I.; Lhomme, J.P. One the relationships between stomatal resistance and leaf temperatures in thermography. J. Agric. For. Meteorol. 2008, 148, 1908-1912. [CrossRef]

153. Maes, W.H.; Steppe, K. Estimating evapotranspiration and drought stress with ground-based thermal remote sensing in agriculture: A review. J. Exp. Bot. 2012, 73, 4671-4712. [CrossRef] [PubMed]

154. Gago, J.; Doutheb, C.; Coopmanc, R.E.; Gallegoa, P.P.; Ribas-Carbob, M.; Flexasb, J.; Escalonab, J.; Medranob, H. UAVs challenge to assess water stress for sustainable agriculture. Agric. Water Manag. 2015, 153, 9-19. [CrossRef]

155. Thenkabail, P.S.; Lyon, J.G.; Huete, A. Hyperspectral remote sensing of vegetation. In Hyperspectral Remote Sensing of Vegetation; Thenkabail, P.S., Lyon, J.G., Eds.; CRC Press: Boca Raton, FL, USA, 2012.

156. Jones, H.G.; Stoll, M.; Santos, T.; Sousa, C.D.; Chaves, M.M.; Grant, O.M. Use of infrared thermography for monitoring stomatal closure in the field: Application to grapevine. J. Exp. Bot. 2002, 53, 2249-2260. [CrossRef] [PubMed]

157. Idso, S.B.; Reginato, R.J.; Jackson, R.D. An equation for potential evaporation from soil, water and crop surfaces adaptable to use by remote sensing, Geophys. Res. Lett. 1977, 4, 187-188. [CrossRef]

158. Idso, S.B.; Jackson, R.D.; Pinter, P.J., Jr.; Reginato, R.J.; Hatfield, J.L. Normalizing the stress-degree-day parameter for environmental variability. Agric. Meteorol. 1981, 24, 45-55. [CrossRef]

159. Idso, S.B. Non-water-stressed baselines: A key to measuring and interpreting plant water stress. Agric. Meteorol. 1982, 27, 59-70. [CrossRef]

160. Itier, B.; Flura, D.; Belabbes, K. An Alternative Way for C.W.S.I. Calculation to Improve Relative Evapotranspiration Estimates-Results of an Experiment over Soybean. Acta Hortic. 1993, 335, 333-340. [CrossRef]

161. Jackson, R.D. Canopy temperature and crop water stress. Adv. Irrig. 1982, 1, 43-48.

162. Walker, G.K.; Hatfield, J.L. Test of the Stress-Degree-Day Concept Using Multiple Planting Dates of Red Kidney Beans. Agron. J. 1979, 71, 967-971. [CrossRef]

163. King, B.A.; Shellie, K.C. Evaluation of neural network modeling to predict non-water-stressed leaf temperature in wine grape for calculation of crop water stress index. Agric. Water Manag. 2016, 167, 38-52. [CrossRef]

164. Jones, H.G. Use of infrared thermometry for estimation of stomatal conductance as a possible aid to irrigation scheduling. Agric. For. Meteorol. 1999, 95, 139-149. [CrossRef]

165. Rojo, F.; Kizer, E.; Upadhyaya, S.; Ozmen, S.; Ko-Madden, C.; Zhang, Q. A Leaf Monitoring System for Continuous Measurement of Plant Water Status to Assist in Precision Irrigation in Grape and Almond crops. In Proceedings of the 5th IFAC Conference on Sensing, Control and Automation Technologies for Agriculture AGRICONTROL 2016, Seattle, WA, USA, 14-17 August 2016.

166. Pinter, P.J.; Fry, K.E.; Guinn, G.; Mauney, J.R. Infrared thermometry: A remote sensing technique for predicting yield in water-stressed cotton. Agric. Water Manag. 1983, 6, 385-395. [CrossRef]

167. Colaizzi, P.D.; Barnes, E.M.; Clarke, T.R.; Choi, C.Y.; Waller, P.M. Estimating soil moisture under low-frequency surface irrigation using Crop Water Stress Index. J. Irrig. Drain. Eng. 2003, 129, 27-35. [CrossRef]

168. Erdem, Y.; Sehuralu, S.; Erdem, T.; Kenar, D. Determination of Crop Water Stress Index for Irrigation Scheduling of Bean (Phaseolus vulgaris L.). Turk J. Agric. 2006, 30, 195-202.

169. Yuan, G.; Luo, Y.; Sun, X.; Tang, D. Evaluation of a crop water stress index for detecting water stress in winter wheat in the North China Plain. Agric. Water Manag. 2003, 64, 29-40. [CrossRef] 
170. Colaizzi, P.D.; Barnes, E.M.; Clarke, T.R.; Choi, C.Y.; Waller, P.M.; Haberland, J.; Kostrzewski, M. Water stress detection under high frequency sprinkler irrigation with water deficit index. J. Irrig. Drain. Eng. 2003, 129, 36-43. [CrossRef]

171. Orta, A.H.; Erdem, Y.; Erdem, T. Crop water stress index for watermelon. Sci. Hortic. 2013, 98, 121-130. [CrossRef]

172. Bellvert, J.; Marsal, J.; Girona, J.; Gonzalez-Dugo, V.; Fereres, E.; Ustin, S.L.; Zarco-Tejada, P.J. Airborne Thermal Imagery to Detect the Seasonal Evolution of Crop Water Status in Peach, Nectarine and Saturn Peach Orchards. Remote Sens. 2016, 8, 39. [CrossRef]

173. Santesteban, L.G.; Di Gennaro, S.F.; Herrero-Langreo, A.; Miranda, C.; Royo, J.B.; Matese, A. High-resolution UAV-based thermal imaging to estimate the instantaneous and seasonal variability of plant water status within a vineyard. Agric. Water Manag. 2017, 183, 49-59. [CrossRef]

174. Baluja, J.; Diago, M.P.; Zorer, R.; Meggio, F.; Tardaguila, J. Assessment of vineyard water status variability by thermal and multispectral imagery using an unmanned aerial vehicle (UAV). Irrig. Sci. 2012, 30, 511-522. [CrossRef]

175. Testi, L.; Goldhamer, D.A.; Iniesta, F.; Salinas, M. Crop water stress index is a sensitive water stress indicator in pistachio trees. Irrig. Sci 2008, 26, 395-405. [CrossRef]

176. Gonzalez-Dugo, V.; Goldhamer, D.; Zarco-Tejada, P.; Fereres, E. Improving the precision of irrigation in a pistachio farm using an unmanned airborne thermal system. Irrig. Sci. 2015, 33, 43-52. [CrossRef]

177. Gonzalez-Dugo, V.; Zarco-Tejada, P.; Berni, J.A.J.; Suárez, L.; Goldhamer, D.; Fereres, E. Almond tree canopy temperature reveals intra-crown variability that is water stress dependent. Agr. For. Meteorol. 2012, 154-155, 156-165. [CrossRef]

178. Gonzalez-Dugo, V.; Zarco-Tejada, P.; Nicolás, E.; Nortes, P.; Alarcón, J.; Intrigliolo, D.; Fereres, E. Using high resolution uav thermal imagery to assess the variability in the water status of five fruit tree species within a commercial orchard. Precis. Agric. 2013, 14, 660-678. [CrossRef]

179. Sezen, S.M.; Yazar, A.; Daşganc, Y.; Yucel, S.; Akyıldız, A.; Tekin, S.; Akhoundnejad, Y. Evaluation of crop water stress index (CWSI) for red pepper with drip and furrow irrigation under varying irrigation regimes. Agric. Water Manag. 2014, 143, 59-70. [CrossRef]

180. Agam, N.; Cohen, Y.; Berni, J.A.J.; Alchanatis, V.; Kool, D.; Dag, A.; Yermiyahu, U.; Ben-Gal, A. An insight to the performance of crop water stress index for olive trees. Agric. Water Manag. 2013, 118, 79-86. [CrossRef]

181. Wang, D.; Gartung, J. Infrared canopy temperature of early-ripening peach trees under postharvest deficit irrigation. Agric. Water Manag. 2010, 97, 1787-1794. [CrossRef]

182. Taghvaeian, S.; Chávez, J.L.; Hansen, N.C. Infrared Thermometry to Estimate Crop Water Stress Index and Water Use of Irrigated Maize in Northeastern Colorado. Remote Sens. 2012, 4, 3619-3637. [CrossRef]

183. García-Tejero, F.; Costa, J.M.; Egipto, R.; Durán-Zuazo, V.H.; Lima, R.S.N.; Lopes, C.M.; Chaves, M.M. Thermal data to monitor crop-water status in irrigated Mediterranean viticulture. Agric. Water Manag. 2016, 176, 80-90. [CrossRef]

184. Kullberg, E.G.; DeJonge, K.C.; Chávez, J.L. Evaluation of thermal remote sensing indices to estimate crop evapotranspiration coefficients. Agric. Water Manag. 2017, 179, 64-73. [CrossRef]

185. Osroosh, Y.; Peters, R.T.; Campbell, C. Daylight crop water stress index for continuous monitoring of water status in apple trees. Irrig. Sci. 2016, 34, 209-219. [CrossRef]

186. Mangus, D.L.; Sharda, A.; Zhang, N. Development and evaluation of thermal infrared imaging system for high spatial and temporal resolution crop water stress monitoring of corn within a greenhouse. Comput. Electron. Agric. 2016, 121, 149-159. [CrossRef]

187. Peters, R.T.; Evett, S.R. Spatial and temporal analysis of crop stress using multiple canopy temperature maps created with an array of center-pivot-mounted infrared thermometers. Trans. ASABE 2007, 50, 919-927. [CrossRef]

188. Evett, S.R.; Peters, R.T.; Howell, T.A. Controlling water use efficiency with irrigation automation: Cases from drip and center pivot irrigation of corn and soybean. In Proceedings of the 28th Annual Southern Conservation Systems Conference, Amarillo, TX, USA, 26-28 June 2006; pp. 57-66.

189. O'Shaughnessy, S.A.; Evett, S.R.; Colaizzi, P.D.; Howell, T.A. Soil water measurement and thermal indices for center pivot irrigation scheduling. In Proceedings of the International Irrigation Association Conference, Anaheim, CA, USA, 2-4 November 2008. 
190. Lamm, F.R.; Aiken, R.M. Comparison of Temperature-Time Threshold-and ET-based irrigation scheduling for corn production. In Proceedings of the 2008 ASABE Annual International Meeting, Providence, RI, USA, 29 June-2 July 2008.

191. O'Shaughnessy, S.A.; Evett, S.R.; Colaizzi, P.D.; Howell, T.A. A crop water stress index and time threshold for automatic irrigation scheduling of grain sorghum. Agric. Water Manag. 2012, 107, 122-132. [CrossRef]

192. Osroosh, Y.; Peters, R.T.; Campbell, C.S.; Zhang, Q. Comparison of irrigation automation algorithms for drip-irrigated apple trees. Comput. Electron. Agric. 2016, 128, 87-99. [CrossRef]

193. DeJonge, K.C.; Taghvaeian, S.; Trout, T.J.; Comas, L.H. Comparison of canopy temperature-based water stress indices for maize. Agric. Water Manag. 2015, 156, 51-62. [CrossRef]

194. Gausman, H.W.; Allen, W.A. Optical parameters of leaves of 30 plant species. Plant Physiol. 1973, 52, 57-62. [CrossRef] [PubMed]

195. Jones, H.G.; Serraj, R.; Loveys, B.R.; Xiong, L.Z.; Wheaton, A.; Price, A.H. Thermal infrared imaging of crop canopies for the remote diagnosis and quantification of plant responses to water stress in the field. Funct. Plant Biol. 2009, 36, 978-989. [CrossRef]

196. Alvino, A.; Centritto, M.; De Lorenzi, F. Photosynthesis response of sunlit and shade pepper (Caspicum anuum) leaves at different positions in the canopy under two water regimes. Aust. J. Plant Physiol. 1994, 21, 377-391. [CrossRef]

197. Williams, W.A.; Loomis, R.S.; Duncan, W.G.; Dovert, A.; Nunez, F. Canopy architecture at various population densities and the growth of grain and corn. Crop Sci. 1968, 8, 303-308. [CrossRef]

198. Alvino, A.; Leone, A. Response to low soil water potential in pea genotypes (Pisum sativum L.) with different leaf morphology. Sci. Hortic. 1993, 53, 21-34. [CrossRef]

199. Tardieu, F.; Simonneau, T. Variability among species of stomatal control under fluctuating soil water status and evaporative demand: Modelling isohydric and anisohydric behaviours. J. Exp. Bot. 1998, 49, 419-432. [CrossRef]

200. Evett, S.R.; Alchanatis, V.L. Improved Analysis of Thermally Sensed Crop Water Status and Mapping Spatial Variability for Site Specific Irrigation Scheduling; Final Report to BARD and the Texas Department of Agriculture on project TIE04-01; USDA-ARS Conservation and Production Research Laboratory: Bushland, TX, USA, 2007.

201. Irmak, S.; Hamman, D.; Bastug, R. Determination of Crop Water Stress Index for Irrigation Timing and Yield Estimation of Corn. Agric. J. 2000, 92, 1221-1227. [CrossRef]

202. Bellvert, J.; Zarco-Tejada, P.J.; Girona, J.; Fereres, E. Mapping crop water stress index in a 'Pinot-noir' vineyard: Comparing ground measurements with thermal remote sensing imagery from an unmanned aerial vehicle. Precis. Agric. 2014, 15, 361-376. [CrossRef]

203. Park, S.; Nolan, A.; Ryu, D.; Fuentes, S.; Hernandez, E.; Chung, H.; O'Connell, M. Estimation of crop water stress in a nectarine orchard using high-resolution imagery from unmanned aerial 2015. In Proceedings of the 21st International Congress on Modelling and Simulation, Goald Coast, Australia, 29 November-4 December 2015.

204. Grant, O.M.; Tronina, L.; Jones, H.G.; Chaves, M.M. Exploring thermal imaging variables for the detection of stress responses in grapevine under different irrigation regimes. J. Exp. Bot. 2007, 58, 815-825. [CrossRef] [PubMed]

205. Ghaemi, A.; Moazed, H.; Rafie Rafiee, M.; Determining, S. CWSI to estimate eggplant evapotranspiration and yield under greenhouse and outdoor conditions. Broomand NASA Iran Agric. Res. 2015, 34, 49-60.

206. Nichols, S.; Zhang, Y.; Ahmad, A. Review and evaluation of remote sensing methods for soil-moisture estimation. SPIE Rev. 2011, 2, 1-17. [CrossRef]

207. Yueh, S.; Entekhabi, D.; O’Neill, P.; Njoku, E.; Entin, J. NASA Soil Moisture Active Passive mission status and science performance. In Proceedings of the 2016 IEEE International Geoscience and Remote Sensing Symposium (IGARSS), Beijing, China, 10-15 July 2016.

208. Mulder, V.L.; de Bruin, S.; Schaepman, M.E.; Mayr, T.R. The use of remote sensing in soil and terrain mapping-A review. Geoderma 2011, 162, 1-19. [CrossRef]

209. Marino, S.; Alvino, A. Proximal sensing and vegetation indices for site-specific evaluation on an irrigated crop tomato. Eur. J. Remote Sens. 2014, 47, 271-283. [CrossRef]

210. Marino, S.; Basso, B.; Leone, A.P.; Alvino, A. Agronomic traits and vegetation indices of two onion hybrids. Sci. Hortic. 2013, 155, 56-64. [CrossRef] 
211. Kalma, J.D.; Mcvicar, T.R.; Mccabe, M.F. Estimating Land Surface Evaporation: A Review of Methods Using Remotely Sensed Surface Temperature Data. Surv. Geophys. 2008, 29, 421-469. [CrossRef]

212. Zhao, T.; Stark, B.; Chen, Y.Q.; Ray, A.; Doll, D. More reliable crop water stress quantification using small unmanned aerial systems (sUAS). IFAC-PapersOnLine 2016, 49, 409. [CrossRef]

213. Zúñiga, C.E.; Khot, L.R.; Jacoby, P.; Sankaran, S. Remote sensing based water-use efficiency evaluation in sub-surface irrigated wine grape vines. In Proceedings of the Proc. SPIE 9866, Autonomous Air and Ground Sensing Systems for Agricultural Optimization and Phenotyping, Baltimore, MD, USA, 17 April 2016.

214. Siegfried, J.A. Remote Sensing to Quantify In-Field Soil Moisture Variability in Irrigated Maize Production; Colorado State University: Fort Collins, CO, USA, 2016.

215. Toureiro, C.; Serralheiro, R.; Shahidian, S.; Sousa, A. Irrigation management with remote sensing: Evaluating irrigation requirement for maize under Mediterranean climate condition. Agric. Water Manag. 2016, 184, 211-220. [CrossRef]

216. Marino, S.; Aria, M.; Basso, B.; Leone, A.P.; Alvino, A. Use of soil and vegetation spectroradiometry to investigate crop water use efficiency of a drip irrigated tomato. Eur. J. Agron. 2014, 59, 67-77. [CrossRef]

217. Nolz, R.; Cepuder, P.; Balas, J.; Loiskandl, W. Soil water monitoring in a vineyard and assessment of unsaturated hydraulic parameters as thresholds for irrigation management. Agric. Water Manag. 2016, 164, 235-242. [CrossRef]

218. Wang, M.; Ellsworth, P.Z.; Zhou, J.; Cousins, A.B.; Sankaran, S. Evaluation of water-use efficiency in foxtail millet (Setaria italica) using visible-near infrared and thermal spectral sensing techniques. Talanta 2016, 152, 531-539. [CrossRef] [PubMed]

(C) 2017 by the authors. Licensee MDPI, Basel, Switzerland. This article is an open access article distributed under the terms and conditions of the Creative Commons Attribution (CC BY) license (http://creativecommons.org/licenses/by/4.0/). 